\title{
UŽI DUBROVAČKI AKVATORIJ U ENGLESKIM PELJARIMA 1811. - 1826. GODINE
}

Daniel DUJMIĆ

Dubrovnik, Hrvatska
UDK: $656.61(262.3) “ 1811 / 1826 “$

DOI: $10.21857 / 94 \mathrm{kl} 4 \mathrm{czkpm}$

Izvorni znanstveni rad

Prihvaćeno: 28. veljače 2021.

U radu su analizirani podatci o dubrovačkom akvatoriju od najjužnijeg rta poluotoka Pelješca, rta Vratnik, do rta Oštra s okolnim otocima, uključujući otok Mljet, koji su navedeni u tri engleska peljara tiskana u prvoj polovici 19. stoljeća. Spomenuti peljari bili su preteča današnjih službenih pomorskih publikacija i sadrže upute za plovidbu Jadranskim morem te su korišteni kao nadopuna pomorskim kartama. Informacije koje su u spomenutim peljarima navedene za dubrovački akvatorij od rta Vratnik do rta Oštra s okolnim otocima, uključujući i otok Mljet, detaljno su analizirane i komparirane sa stvarnim stanjem prema relevantnim povijesnim izvorima i onodobnim pomorskim kartama, kao i prema suvremenim hrvatskim pomorskim kartama i publikacijama u izdanju Hrvatskog hidrografskog instituta. Time je utvrđena točnost i pouzdanost objavljenih podataka te njihovo odstupanje od stvarnog stanja.

Ključne riječi: pomorske publikacije, peljari, dubrovački akvatorij, 19. stoljeće, Jadransko more.

\section{UVOD}

Pomorcima je iznimno važno imati pouzdane karte plovidbenih područja, ali same karte nisu dovoljne. Naime, za sigurnu plovidbu, a koja je preduvjet svakog uspješnog plovidbenog pothvata, treba uzeti u obzir brojne čimbenike. Najvažniji od njih svakako su vremenske prilike s osobitim naglaskom na vjetrove i stanje mora, zatim morske struje, morske mijene, objekti pomorske signalizacije i sl. U novije vrijeme sve više dobivaju na važnosti i brojni plovidbeni propisi koji se odnose na peljarenje, sheme odvojene plovidbe, plovidbu kroz zaštićena područja itd., i koje također treba uzeti u obzir prilikom planiranja putovanja.

U prošlosti su pomorske karte uistinu i sadržavale slične informacije, ali kako je $s$ vremenom rasla količina dostupnih informacija, tako je njihovo zapisivanje na same karte u praksi postalo neizvodivo. Danas je za dolazak broda u luku potrebno mnoštvo informacija i koje bi zapisane na pomorskoj karti istu učinile nepreglednom i neupotrebljivom za samu navigaciju. Stoga, u svrhu pružanja dodatnih informacija važnih za plovidbu određenim područjem, postoje različite 
pomorske publikacije kao što su peljari ${ }^{1}$ (engl. Sailing Directions) koji sadrže informacije što služe kao nadopuna kartama. ${ }^{2}$ Štoviše, peljari spadaju u obvezne publikacije koje su brodovi po propisima dužni imati te ih treba redovito ažurirati pripadajućim ispravcima ${ }^{3}$ kao što je propisano i za pomorske karte. ${ }^{4}$

Peljar kao pomorska publikacija nije proizvod novog doba, jer se Perilpl Pseudo-Skilaka može smatrati najstarijim plovidbenim priručnikom Sredozemlja odnosno Jadrana. Tijekom razdoblja iz kojeg potječu tri analizirana peljara bio je aktualan peljar Portolano del Mare Adriatico Giacoma Marienija iz 1830. godine. ${ }^{5}$

Prema odlukama SOLAS Konvencije, ${ }^{6}$ peljari danas spadaju u obvezne pomorske publikacije koje su brodovi dužni posjedovati. SOLAS Konvencija tako navodi karte i pomorske publikacije kao specijalizirane karte i knjige, odnosno datoteke u kojoj su iste pohranjene, a izdaju ih ovlašteni hidrografski instituti ili druge vladine organizacije i time udovoljavaju zahtjevima pomorske plovidbe. Konvencija ujedno nalaže kako svi brodovi moraju imati ažurirane karte i publikacije za područje u kojem plove. ${ }^{7}$

1 Peljar je priručnik za plovidbu koji daje podatke za najpovoljniji izbor rute u nekom području. Sadrži informacije kao što su geografski opisi obala i orijentacija, hidrografske, navigacijske, oceanografske i klimatološke prilike, upute za plovidbu, podatci o lukama zakloništima i sidrištima, podatci o uslugama i mogućnostima opskrbe, pomorsko-upravni i druge propisi, oznake na plovnim putovima itd. Peljar, u: Pomorski leksikon, gl. ur. Anton Simović, Zagreb, 1990., 580.

2 Potrebno je napomenuti kako se u pomorskoj praksi danas uglavnom koriste pomorske karte i publikacije u digitalnom obliku.

3 U tu svrhu Hrvatski hidrografski institut izdaje publikaciju Oglas za pomorce koja izlazi mjesečno i služi za ispravljanje odnosno ažuriranje karata i publikacija u izdanju Hrvatskog hidrografskog instituta, dok se primjerice engleski Admiralty Sailing Directions ažuriraju pomoću publikacije British Admiralty Notices to Mariners koja izlazi tjedno.

4 Hrvatsko zakonodavstvo u Pravilniku o službenim pomorskim navigacijskim kartama $i$ publikacijama, njihovom sadržaju, načinu i uvjetima izrade, izdavanja $i$ održavanja definira Peljar I. Jadransko more - istočna obala u izdanju Hrvatskog hidrografskog instituta kao službenu pomorsku navigacijsku publikaciju namijenjenu plovnim objektima na koje se primjenjuje SOLAS Konvencija. Također se propisuje i njegovo ažuriranje publikacijom Oglas za pomorce koja je definirana kao mjesečna publikacija u kojoj se na hrvatskom i engleskom jeziku objavljuju sve promjene i dopune za ažuriranje službenih pomorskih papirnatih navigacijskih karata i službenih pomorskih navigacijskih publikacija u izdanju Hrvatskog hidrografskog instituta. Pravilnik o službenim pomorskim navigacijskim kartama i publikacijama, njihovu sadržaju, načinu i uvjetima izrade, izdavanja i održavanja, Narodne Novine, 42/2016, 4. 5. 2016.

5 Mithad Kozličić, Pomorske karte i plovidbeni priručnici istočnog Jadrana tijekom povijesti, Miscellanea Hadriatica et Mediterranea, 1 (1), Zadar, 2013., 169 - 197.

6 International Convention of the Safety of Life at Sea (SOLAS) je međunarodna konvencija o zaštiti života na moru i temeljni međunarodni instrument sigurnosti na moru. Prva verzija Konvencije nastala je 1914. godine kao reakcija na tragediju RMS-a Titanic. Danas je na snazi peta verzija konvencije iz 1974. godine nadopunjena brojnim amandmanima i protokolima. Konvenciju su do kraja 2018. godine potpisale 164 države.

7 Više u: SOLAS Consolidated Edition 2014, London, 2014. 
Rad prikazuje analizu tri engleska peljara iz prve polovice 19. stoljeća te provjerava točnost i kvalitetu objavljenih informacija koje se odnose na plovidbu užim dubrovačkim akvatorijem od najjužnijeg rta Pelješca (rta Vratnik) do rta Oštra s okolnim otocima, uključujući i otok Mljet. Peljari prikazani u radu preteče su današnjih Admiralty Sailing Directions koje izdaje Hidrografski ured Ujedinjenog Kraljevstva ${ }^{8}$ i predstavljaju dio pomorskog nasljeđa te daju uvid u jedno od razdoblja povijesnog razvoja pomorskih karata i publikacija.

Sve do Napoleonovih ratova, odnosno do početka 19. stoljeća, engleske pomorske karte i publikacije Jadranskog mora tiskane su koristeći podatke iz postojećih mletačkih karata i publikacija, a koje su bile relativno nepouzdane. Prve britanske izmjere Jadrana izvršili su pripadnici britanske Kraljevske mornarice u razdoblju od 1800. do 1801. godine. Na osnovi spomenutih izmjera 1803. godine tiskane su pomorske karte Jadranskog mora u izdanju Hidrografskog ureda Ujedinjenog Kraljevstva. ${ }^{9}$ Tijekom razdoblja od 1811. do 1815. godine pripadnici britanskih oružanih snaga izvršili su izmjere otoka Visa, dok su nakon završetka Napoleonovih ratova, točnije u razdoblju od 1817. do 1819. godine, izvršene opsežne zajedničke britansko-austrijsko-talijanske izmjere Jadrana. ${ }^{10}$

Upravo se tijekom Napoleonovih ratova javila potreba za pouzdanim pomorskim kartama i publikacijama Jadranskog mora namijenjenih korištenju na brodovima britanske Kraljevske mornarice. Naime, nakon pobjeda u pomorskim bitkama kod Nila (1798. godine), a zatim i kod Trafalgara (1805. godine), britanska Kraljevska mornarica ostvarila je pomorsku dominaciju na Sredozemlju te se vremenom težište pomorskih operacija premješta na Jadran. Pobjedom britanske Kraljevske mornarice u bitki kod Visa (1811. godine) uspostavljena je britanska pomorska dominacija na Jadranu i koja traje sve do završetka Napoleonovih ratova. ${ }^{11}$

8 United Kingdom Hydrographic Office.

9 Prvim britanskim izmjerama Jadrana rukovodio je časnik britanske Kraljevske mornarice Robert Nellson. Više o britanskim izmjerama Jadrana početkom 19. stoljeća u: Mirela Slukan Altić, The British Contribution to the Charting of the Adriatic Sea, The Cartographic Journal, 52(4), 2015., $305-317$.

$10 \mathrm{Na}$ osnovi zajedničkih britansko-austrijsko-talijanskih izmjera tiskane su pomorske karte edicije Carta di cabottagio del mare Adriatico. Spomenute karte objavio je Vojno-geografski institut iz Milana tijekom razdoblja od 1822. do 1824. godine i one predstavljaju prekretnicu u povijesnom razvoju pomorske kartografije Jadrana. Više u: Josip FARIČıć, Lena MirošEvić, Carta di cabotaggio del Mare Adriatico (1822-1824): A Turning-Point in the Development of Adriatic Maritime Cartography, Imago mundi, 69(1), 2017., 99 - 111.

11 Britanska nastojanja za pomorskom dominacijom na Sredozemlju datiraju još od zauzimanja Gibraltara (1704. godine). Važnu ulogu imalo je i britansko zauzimanje Malte (1800. godine) koje je tijekom Napoleonovih ratova između ostalog omogućilo i borbena djelovanja britanske Kraljevske mornarice na Jadranu. 


\section{LAURIE AND WHITTLE'S NEW SAILING DIRECTIONS FOR THE MEDITERRANEAN SEA IZ 1811. GODINE ${ }^{12}$}

Engleski peljar s početka 19. stoljeća sadrži 112 stranica s opisima i uputama za plovidbu Sredozemljem uključujući i Jadransko more, odnosno Mletački zaljev. Izdavači su Robert Laurie ${ }^{13}$ i James Whittle iz Londona. ${ }^{14}$

Nije navedeno čije su izmjere korištene za izradu peljara, međutim spominje se kako je peljar „sastavljen iz pouzdanih izvora“15 uključujući i bilješke slavnog admirala Horatia Nelsona, kapetana britanske Kraljevske mornarice Rivesa te Josepha Dessioua, autora karte New Chart of the Mediterranean Sea (Slika 1) kojoj je peljar predviđen kao dodatak. ${ }^{16}$

Peljar je podijeljen na 10 poglavlja (Sections) numeriranih od I. do X. Poglavlje V. naslova "Gulf of Venice“ (str. 68 - 73) opisuje Jadran i podijeljeno je na dva dijela. U prvom dijelu poglavlja (str. 68 - 73) su upute za plovidbu Jadranom od rta Otranto do rta Linguetta, dok drugi dio (str. 73) sadrži opće upute za plovidbu Jadranom. Iz navedenog je već po broju stranica vidljivo kako je cjelokupno područje Jadrana vrlo površno i nedovoljno obrađeno na svega šest stranica, sa svega jednom nepotpunom stranicom općih uputa. ${ }^{17}$

12 Autor peljara nije naveden, ali postoji mogućnost kako je to bio britanski kartograf John Purdy koji je još prije 1812. godine odnosno u razdoblju tiskanja peljara (1811.) bio zaposlenik tvrtke Laurie and Whittle.

13 Robert Laurie (1755? - 1836.), britanski bakrorezac škotskog porijekla, autor je brojnih umjetničkih djela i za svoj rad i inovacije na području grafičkih tehnika dobio je više priznanja. Laurie, Robert, Dictionary or National Biography, Vol. XXXII., (ed. Sidney Lee), New York - London, 1892., 211.

14 Laurie and Whittle, londonska tvrtka za tiskanje i prodaju pomorskih karata i publikacija. Poslovanje tvrtke pod spomenutim imenom započinje 1794. godine kada su Robert Laurie i James Whittle kao dotadašnji zaposlenici nastavili poslovanje preuzevši tvrtku od prethodnog vlasnika Roberta Sawyera. Tvrtka je pod imenom Laurie and Whittle poslovala do 1812. godine kada Roberta Laurieja nasljeđuje njegov sin Richard Holmes Laurie nakon čega tvrtka mijenja ime u Whittle and Laurie. Nakon smrti Jamesa Whittlea 1818. godine Richard Holmes Laurie postaje jedini vlasnik te tvrtka mijenja ime u Richard Holmes Laurie. Nešto prije 1812. godine za Laurie and Whittle počinje raditi britanski kartograf John Purdy, autor peljara The New Sailing Directory for the Mediterranean Sea, the Adriatic Sea or the Gulf of Venice, the Archipelago and Levant, the Sea of Marmara and the Black Sea, tiskanog 1826. godine. Laurie, Robert, Dictionary or National Biography, Vol. XXXII., 211.

15 „(...) compiled from the best authorities.“

16 New Chart of the Mediterranean Sea je pomorska karta iz 1811. godine u izdanju Laurie and Whittlea. Kartu je izradio britanski kartograf Joseph Dessiou koristeći postojeće španjolske i francuske pomorske karte, kao i pomorske karte Jadrana koje je tiskao Ludovico Furlanetto. Prilikom izrade karte korištene su i bilješke admirala Horatia Nelsona. Laurie and Whittle's New Chart of the Mediterranean Sea, http://digitalarchive.mcmaster.ca/islandora/object/macrepo\%3A79186, (posjećeno 10.9.2020.).

17 Usporedbe radi, engleski peljar Jadrana The Adriatic Pilot iz druge polovice 19. stoljeća (točnije iz 1861. godine) sadrži 244 stranice i odnosi se isključivo na Jadransko more, a ne obrađuje ga kao 


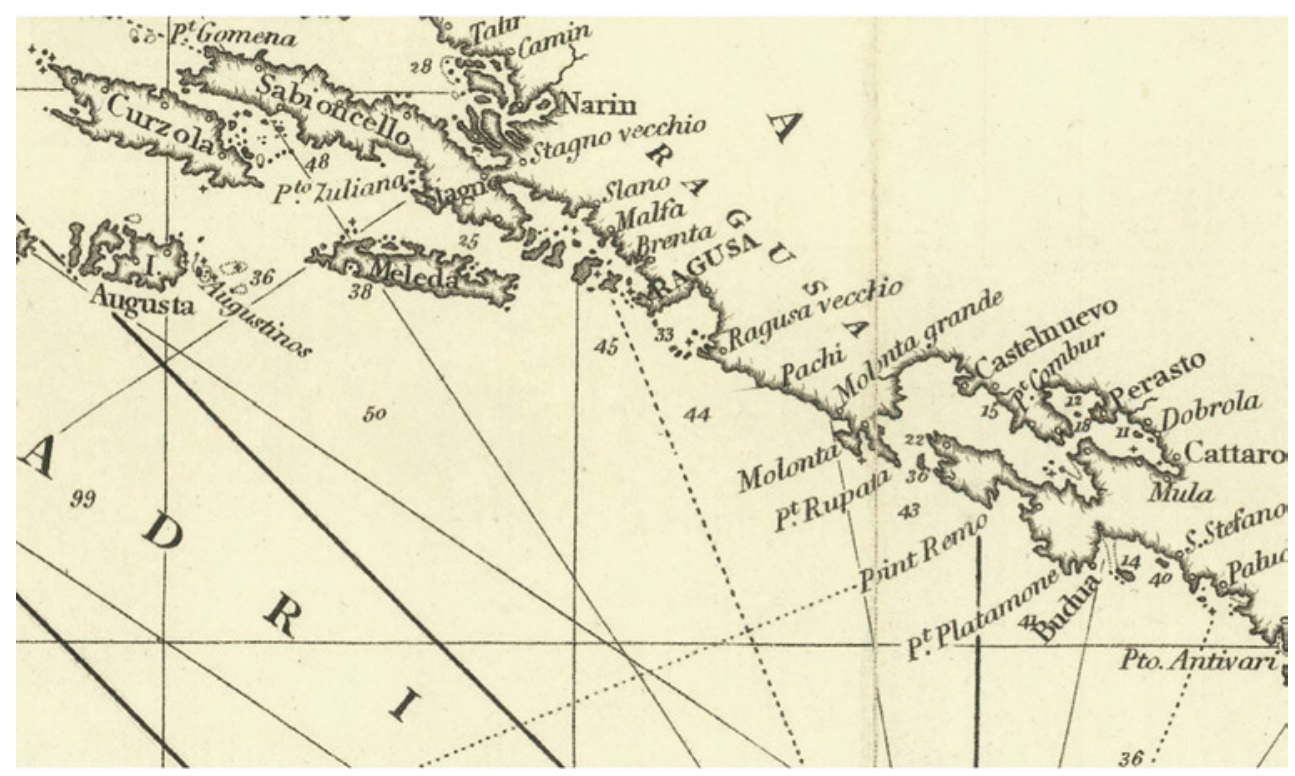

SLIKA 1. Isječak pomorske karte Laurie and Whittle's New Chart of the Mediterranean Sea iz 1811. godine na kojem je prikazano šire dubrovačko područje od otoka Korčule do Boke kotorske (Izvor: Laurie and Whittle's New Chart of the Mediterranean Sea, http:// digitalarchive.mcmaster.ca/islandora/object/macrepo\%3A79186, posjećeno 10.9. 2020.)

Kursovi i azimuti u peljaru su pravi, ako nije navedeno drukčije. To bi drugim riječima značilo da pomorci trebaju znati vrijednost magnetske varijacije ${ }^{18} \mathrm{u}$ području u kojem plove kako bi mogli na kompasu, koji je tada bio isključivo magnetski, postaviti kurs prema uputama iz peljara. U peljaru izostaju podatci o magnetskoj varijaciji za područje Dubrovnika, ali magnetska varijacija 1809. godine za područje Dubrovnika (premaizmjerama Beautemps-Beaupréa) iznosila je $15^{\circ} 48^{\prime} \mathrm{W} .{ }^{19} \mathrm{Na}$ engleskoj pomorskoj karti New Chart of The Mediterranean Sea iz 1797. godine magnetska varijacija za područje Jadrana iznosila je $17^{\circ} \mathrm{W}^{20}$

dio Sredozemnog mora kao što je to slučaj s peljarima analiziranima u radu. Za izradu spomenutog peljara korištene su zajedničke englesko-austrijsko-talijanske izmjere koje su vršili Campana, Visconti i Smyth, kao i Peljar Jadranskog mora, Portolano del Mare Adriatico Giacoma Marienija iz 1830. godine. Više u: The Adriatic Pilot, London, 1861.

18 Magnetska varijacija je horizontalni kut koji u točki stajališta (u kojoj se nalazi kompas) zatvaraju smjerovi magnetnog pola i sjevernog geografskog pola. The Dictionary of Physical Geography, gl. ur. David S. G. Thomas, Hoboken, 2016., 326.

19 Mithad Kozličić, Istočni Jadran u djelu Beautemps-Beaupréa, Split, 2006., 31.

20 New Chart of The Mediterranean Sea iz 1797. godine u izdanju W. Heather \& Co. London. New Chart of The Mediterranean Sea, https://www.loc.gov/item/2012593220/, (posjećeno 10. 9. 2020.). 


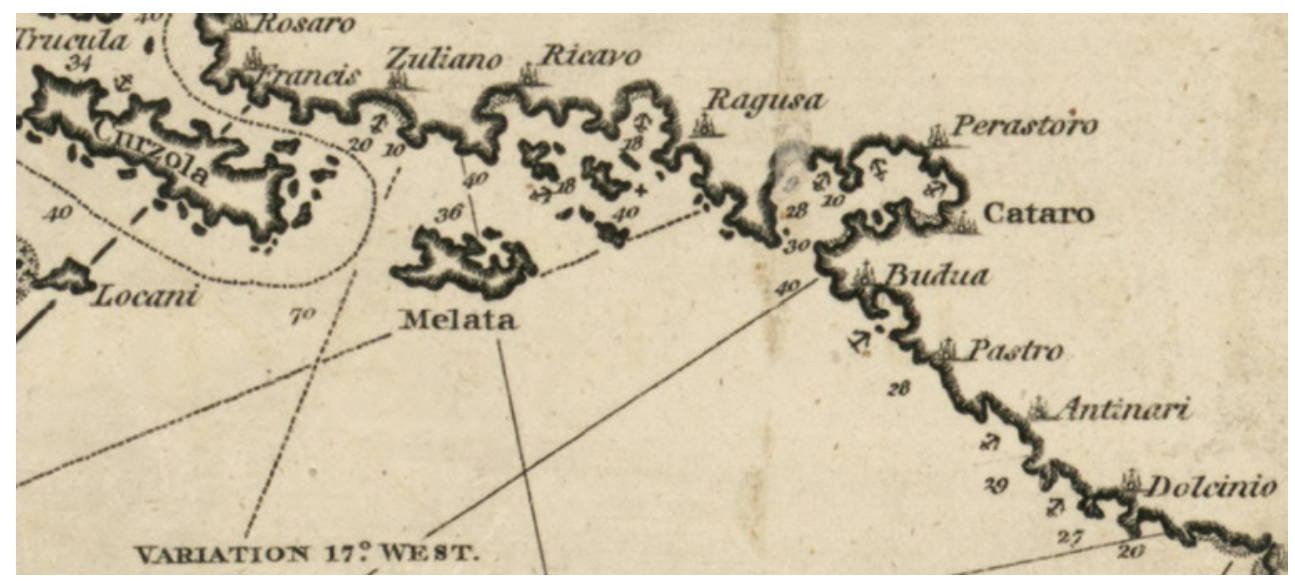

SLIKA 2. Isječak pomorske karte New Chart of The Mediterranean Sea iz 1797. godine na kojem je prikazano područje od otoka Korčule do Ulcinja, kao i vrijednost magnetske varijacije za spomenuto područje (Izvor: New Chart of The Mediterranean Sea, https://www. loc.gov/item/2012593220/, posjećeno 10.9.2020.)

(Slika 2). Usporedbe radi, magnetska varijacija za 2020. godinu iznosi $4^{\circ} 17^{\prime} \mathrm{E}$ na području Dubrovnika,,$^{21} 4^{\circ} 21^{\prime}$ E na području Mljetskog kanala ${ }^{22}$ i $4^{\circ} 19^{\prime}$ E na području rta Oštra i Boke kotorske. ${ }^{23}$

U uputama za plovidbu Jadran je opisan od ulaska kod Otranta, nastavljajući zapadnom obalom prema sjeverozapadu do Venecije te zatim istočnom obalom prema jugoistoku sve do izlaska iz Jadrana kod rta Linguetta. ${ }^{24}$

Analizirano područje prikazano je na stranici $72 \mathrm{u}$ dva ulomka, od kojih se jedan odnosi na otok Mljet, a drugi na Dubrovnik. Slijedeći generalni smjer uputa za plovidbu, prvo je opisan otok Mljet kojem se u plovidbi prema Dubrovniku prilazi iz N, zatim slijedi Dubrovnik te rt Oštra i Boka kotorska.

„Otok Mljet (Melida Island) nalazi se na udaljenosti od oko 3 lige u istočno od otoka Korčule (Curzula) i 2 lige udaljen je od obale poluotoka Pelješca (Sabioncello). Otok je 7 liga dug i na njegovu istočnom kraju je otočić Badanj (Mesa) iza kojega se brod može zakloniti od svih vjetrova. Uplovljava se između hridi i otočića koji treba ostaviti po lijevoj strani. Hrid je zaobljena i oblika

21 Pomorska karta MK-26 Dubrovnik, Split, 2015.

22 Pomorska karta MK-25 Ston, Split, 2015.

23 Pomorska karta MK-27 Boka kotorska, Split, 2015.

${ }_{24}$ Zanimljivo je kako su u tekstu od svih nabrojanih jadranskih luka velikim tiskanim slovima istaknuti jedino Venecija i Dubrovnik, što ukazuje na njihov tadašnji značaj. Laurie and Whittle's New Sailing Directions for the Mediterranean Sea, London, 1811., 69 i 72. 
štruce, a kada se zađe iza otočića brod ima dovoljno prostora. Oko 3 lige istočno od otoka Mljeta je otok Koločep (Calamota) na kojem se nalazi crkva. Zapadno od otoka Koločepa nalaze se četiri otoka između kojih su prikladni prolazi, kao i prikladna sidrišta. Najzapadniji je otok Olipa (Ladro) na čijoj se zapadnoj strani nalazi istoimena uvala, odnosno luka Olipa (Port Ladro).“25

Analizirajući tekst peljara, nailazimo na uporabu stare mjerne jedinice za duljinu - lige. Pretpostavljajući kako se u peljaru koristi engleska liga i uzimajući u obzir da jedna engleska liga iznosi tri nautičke milje, zaključuje se kako je otok Mljet udaljen $9 \mathrm{M}$ od otoka Korčule i $6 \mathrm{M}$ udaljen od obale poluotoka Pelješca te da je otok Mljet dug $21 \mathrm{M} .{ }^{26}$ Prema službenim hrvatskim pomorskim kartama, otok Mljet od otoka Korčule udaljen je otprilike 9,3 M, mjereno od rta Ražnjić na Korčuli do rta Sparožni na Mljetu. Udaljenost između Mljeta i Pelješca, odnosno širina Mljetskog kanala većinom je između 4,2 i 4,8 M. Duljina otoka je nepunih 20 M (19,7 M). Navodi u peljaru relativno su precizni te postojeća odstupanja u praksi i nemaju utjecaja na plovidbu.

U peljaru se spominje otočić Mesa, odnosno otočić Badanj u uvali Sobra ${ }^{27}$ koja se na tadašnjim kartama označavala kao Mezza Meleda. ${ }^{28}$ Hrid na koju se peljar referira je hrid Seperka i koja se nalazi na sjevernoj strani ulaza u uvalu Sobra. Spomenuti otočić Badanj (Mesa) je danas poluotok, jer je na njegovoj južnoj strani izgrađeno trajektno pristanište Sobra..$^{29}$ Međutim, naveden je pogrešan podatak kako se otočić Badanj, odnosno uvala Sobra, nalazi na istočnom kraju

25 „Melida Island lies about 3 leagues to the eastward of Curzula, and 2 leagues from the land of Sabioncello: this island is about 7 leagues in length, and at its east end lies a small island, called Mesa, behind which you may lie sheltered in all winds; you may sail between this island and a rock, leaving it on your larboard side; the rock is round, like a loaf, and when you are in you will find room enough. East of this island, about 3 leagues, is the Island Calamota, on which stands a church; to the westward of Calamota are four other islands, with good passages between. and anchorage within them; the westernmost is called Ladro, and has a port of that name on its west side." Laurie and Whittle's New Sailing Directions for the Mediterranean Sea, 72.

26 Spomenute udaljenosti otoka Mljeta od otoka Korčule te od poluotoka Pelješca istovjetne su udaljenostima prema pomorskoj karti područja Dubrovačke Republike Vincenza di Lucija tiskanoj oko 1800. godine. Međutim, duljina otoka Mljeta prema navedenoj karti nešto je veća i iznosi oko 23 M. Pomorski muzej, Dubrovnik, Pomorska karta područja Dubrovačke Republike, Vincenzo di Lucio, ca. 1800., Zbirka pomorskih i zemljopisnih karata i atlasa, inv. br. DUM PM 227.

27 Uvala Sobra $\left(42^{\circ} 44,6^{\prime} \mathrm{N} 17^{\circ} 37,1^{\prime} \mathrm{E}\right)$ je velika uvala na sjevernoj obali otoka Mljeta s lukom Sobra koja je ujedno i glavna luka na otoku, kao i pristanište za mjesto Babino Polje. Peljar I. Jadransko more - istočna obala, Split, 2012., 270.

28 Pomorski muzej, Dubrovnik, Pomorska karta područja Dubrovačke Republike.

29 Odabir pozicije za izgradnju trajektnog pristaništa u Sobri dodatno potvrđuje vjerodostojnost informacije o zaklonjenosti od vjetrova. 
otoka Mljeta. ${ }^{30}$ Nekada otočić, a danas rt Badanj udaljen je oko 6,5 M zračne linije od istočnog kraja Mljeta, odnosno rta Debeli.

Udaljenost od Mljeta do Koločepa u peljaru je procijenjena na 3 lige odnosno $9 \mathrm{M}$, dok je stvarna udaljenost približno $10 \mathrm{M}$. Nejasno je na koju se točno crkvu peljar referira jer je na Koločepu bilo više crkvi, vidljivih ovisno o smjeru prilaska otoku. ${ }^{31} \mathrm{U}$ navedenu skupinu od četiri otoka zapadno od Koločepa ubrajaju se otoci Lopud, Šipan, Jakljan i Olipa. Pod prikladnim prolazima smatraju se ulazi u Koločepski kanal i koji se nalaze između navedenih otoka (Koločepska vrata, Lopudska vrata, Prolaz Harpoti, Veliki Vratnik, Mali Vratnik) i u kojima se kao i u Koločepskom kanalu brodovi mogu usidriti odnosno zakloniti od vremenskih neprilika. Naime, Koločepski kanal nalazi se u zavjetrini prevladavajućih vjetrova te je služio kao sigurno zaklonište brodovima koji su plovili uz istočnu obalu Jadrana. ${ }^{32}$ Važnost Koločepskog kanala očituje se u tome i što su Elafiti prvo otočje na putu od Otrantskih vrata duž istočne obale Jadrana. Također, kanal je predstavljao i plovni put između dvaju vodećih urbanih središta Dubrovačke Republike Dubrovnika i Stona. ${ }^{33}$

Nakon otoka Mljeta slijedi opis Dubrovnika: „Dubrovnik (Ragusa) - nalazi se oko 5 M od Koločepa u smjeru SE za E (123045”) i oko 6 liga (18 M) istočno od otoka Mljeta. Dubrovnik se lako može prepoznati po crkvi koja se nalazi na brdu iznad grada. Ispred Dubrovačkog zaljeva (Bay of Ragusa) nalaze se četiri otoka,

30 Podatak kako se otočić Badanj, odnosno uvala Sobra, nalazi na istočnom kraju otoka Mljeta pogrešno je naveden, iako je na pomorskoj karti Laurie and Whittle's New Chart of the Mediterranean Sea iz 1811. godine i kojoj peljar služi kao dodatak prikazano drugačije. Spomenuti podatak kako se uvala Sobra nalazi na samom istočnom kraju otoka Mljeta prikazan je na starijem izdanju pomorske karte New Chart of The Mediterranean Sea iz 1797. godine u izdanju W. Heather \& Co. London (Slika 2). New Chart of The Mediterranean Sea, https://www.loc.gov/item/2012593220/, (posjećeno 10. 9. 2020.).

31 Budući da u peljaru nije naveden smjer prilaska otoku, ne može se sa sigurnošću utvrditi o kojoj je crkvi riječ. Najvjerojatnije je u pitanju jedna od sljedeće tri crkve: župna crkva Velike Gospe u Gornjem Čelu, crkva svetog Nikole na groblju ili crkva svetog Antuna Padovanskog u Donjem Čelu. Od tri spomenute crkve najuočljivija je crkva svetog Nikole na groblju koja se nalazi na uzvisini, stoga je za pretpostaviti kako se peljar referira na nju. O crkvama na Koločepu i njihovim lokacijama tijekom povijesti više u: Krešimir REgAN, Branko NADILo, Ranoromaničke i predromaničke crkve na Koločepu (I.), Građevinar, 58 (4), Zagreb, 2006., 317 - 323. i Krešimir REGAN, Branko NADilo, Ranoromaničke i predromaničke crkve na Koločepu (II.), Gradevinar, 58 (5), Zagreb, 2006., 405 - 412. Podatak kako se na otoku Koločepu nalazi crkva kao orijentir zabilježen je i na pomorskoj karti područja Dubrovačke Republike Vincenza di Lucija. Međutim, spomenuta karta nije dovoljno precizna kako bi se moglo sa sigurnošću utvrditi pozicija crkve. Pomorski muzej, Dubrovnik, Pomorska karta područja Dubrovačke Republike.

32 Sidrište u Koločepskom kanalu i danas koriste manja plovila u slučaju olujnih vjetrova te mrtvog mora iz II. kvadranta.

33 Damir MAgAš, Josip FARIČıć, Maša SuRIć, Elafitsko otočje - fizičko geografska obilježja u funkciji društveno-gospodarskog razvitka, Geoadria, 6 (1), Zadar, 2001., 31 - 55. 
međusobno na stanovitoj udaljenosti. Između otoka su prolazi u kojima je more duboko. Na otoku koji je najbliži Dubrovniku (Ragusa point) nalazi se crkvica svetog Marka. Luka odnosno sidrište donekle je izloženo SE vjetrovima. Na suprotnoj strani zaljeva je Cavtat (Old Town of Ragusa) ispred kojega je sidrište dubine 6 - 8 hvati $(11-14,6 \mathrm{~m}){ }^{\text {“' } 34}$

Pozicija Dubrovnika je u stvarnosti 4-6 M od Koločepa, ovisno mjeri li se od istočnog ili zapadnog kraja otoka. Udaljenost od Mljeta do Dubrovnika je 16,2 M mjereno od rta Debeli na Mljetu do subočice ${ }^{35}$ ulaza u dubrovačku staru gradsku luku. Navedena odstupanja su prihvatljiva jer u praksi nemaju utjecaja na plovidbu.

Spomenuta crkva na brdu iznad Dubrovnika je crkva svetog Srđa iz 12. stoljeća koja se nalazila na brdu Srđ i koja je srušena prilikom gradnje utvrde Imperijal. Budući da je utvrda Imperijal građena za vrijeme francuske uprave u razdoblju od 1806. do 1810. godine, ${ }^{36}$ crkva ni u kojem slučaju nije mogla biti orijentir u godini izdavanja peljara (1811.). Ova pogreška je vrlo bitna jer se ponavljala i u peljarima kasnijih godišta, iz čega se može zaključiti kako su podatci bili prepisivani bez provjere stanja na terenu te je trebalo dugo vremena kako bi se ažurirali. ${ }^{37}$

Hidronim Dubrovački zaljev ne postoji, ali pod nazivom Bay of Ragusa autor podrazumijeva područje koje obuhvaća Župski zaljev te Lokrumski prolaz. To je zaljev na čijem se zapadnom kraju nalazi grad Dubrovnik (danas stara gradska jezgra), a na istočnom kraju se nalazi gradić Cavtat. Četiri otoka u spomenutom Dubrovačkom zaljevu su Lokrum, Mrkan, Bobara i Supetar koji i jesu međusobno relativno udaljeni. Naime, Lokrum se nalazi neposredno ispred stare dubrovačke gradske luke, a ostala tri otoka nalaze se u blizini Cavtata, tako

34 „RAGUSA is about 5 miles to the S.E. by E. of Calamota, and about 6 leagues to the eastward of Melida: this city is easily known by a church which stands on a mountain above it; and before the Bay of Ragusa lie 4 islands, at some distance from each other, with deep water channels between them; of which, that nearest to Ragusa Point has a small chapel on it, dedicated to St. Mark. The harbour is exposed, in some degree, to the. S. E. winds, but it is perfectly safe for ships to lie in. On the opposite side of the bay is the old Town of Ragusa, near which you may anchor in 6 or 8 fathoms water." Laurie and Whittle's New Sailing Directions for the Mediterranean Sea, 72.

35 Subočice (engl. abeam) je položaj objekta označen smjerom koji ide okomito na uzdužnicu broda. Određen je pramčanim kutom $\mathrm{L}=90^{\circ}$ (lijevo ili desno) ili kompasnim azimutom $\omega(\mathrm{k})=\mathrm{K}(\mathrm{k}) \pm$ 90. Subočice, u: Pomorski leksikon, gl. ur. Anton Simović, Zagreb, 1990., 778.

36 Stanko Piplović, Graditeljstvo u Dalmaciji za francuske uprave, u: Adris, Zbornik radova, ur. Davorin Rudolf, Zagreb - Split, 2012., 75 - 102.

37 Primjerice, u engleskom peljaru iz 1841. godine New Sailing Directions for the Mediterranean Sea, the Adriatic, or Gulf of Venice, the Black Sea, Grecian Archipelago, and the Seas of Marmara and $A z o v$, koji je izdan više od 30 godina nakon gradnje utvrde Imperijal, i dalje se navodi kako je Dubrovnik prepoznatljiv po crkvi koja se nalazi na brdu iznad grada. New Sailing Directions for the Mediterranean Sea, the Adriatic, or Gulf of Venice, the Black Sea, Grecian Archipelago, and the Seas of Marmara and Azov, London, 1841., 176. 
da je udaljenost između Lokruma i Bobare oko 2,9 M. Međutim, na otoku koji je najbliži Dubrovniku, a to je otok Lokrum, danas ne postoji crkvica svetog Marka, već crkvica Navještenja te ostatci crkve svete Marije iz 12./13. stoljeća u sklopu kompleksa Benediktinskog samostana.

Navod kako je luka, odnosno sidrište, izložena SE vjetru je točan, međutim gradsku luku iz spomenutog smjera štiti valobran Kaše. Sidrište je izloženo i SW vjetrovima ako se sidri preblizu gradskoj luci. ${ }^{38}$ Navedeno potvrđuje i najnovije izdanje hrvatskog peljara Peljar I. Jadransko more - istočna obala iz 2012. godine, gdje stoji kako je sidrište ispred luke izloženo jugu (SE vjetar) i SW vjetru koji mogu uzrokovati jako valovito i teško more. ${ }^{39}$

Nasuprot Dubrovnika (Raguse), odnosno na drugoj strani (Dubrovačkog) zaljeva, nalazi se Cavtat što je točno. Međutim, korištenje ove terminologije može dovesti do zabune jer se danas pod Old Town of Ragusa podrazumijeva stara gradska jezgra Dubrovnika, a Ragusa-Vecchia (Stari Dubrovnik) na pomorskim je kartama tog vremena bilo ime Cavtata, čime se zapravo reflektira tradicija antičkog Epidaurusa. ${ }^{40}$ Dubine sidrišta ispred Cavtata od 6 do 8 hvati (približno od 11 do 14,6 metara) navedene u peljaru prilično su točne u usporedbi s dubinama na suvremenim pomorskim kartama u izdanju Hrvatskog hidrografskog instituta. ${ }^{41}$

Drugi dio poglavlja na str. 73 pod naslovom Some General Directions for the Navigation of The Gulf of Venice odnosi se na opće upute za plovidbu, s obzirom na vjetrove i morske struje. ${ }^{42}$ Upute su prilično oskudne (svega pola stranice) i uglavnom se svode na upute za plovidbu prema Veneciji kao najvažnijoj jadranskoj luci, odnosno na opis najpovoljnije rute prema Veneciji. Čak i ovakve oskudne upute savjetuju plovidbu istočnom obalom Jadrana kod ulaska i kod izlaska, a kako bi se donekle iskoristile morske struje za koje se navodi da su u Jadranskom moru uglavnom južnog smjera. ${ }^{43}$ Spomenuta tvrdnja o smjerovima

38 U vrijeme tiskanja peljara izloženost sidrišta SW vjetrovima bila je još veća nego danas, jer tada nije postojao lukobran (Porporela) čija je gradnja započela 1873. godine.

39 Peljar I. Jadransko more - istočna obala, 280.

40 Primjerice, kao na Beautemps-Beaupreovoj generalnoj karti istočne obale Jadrana od Stona do Spiča iz oko 1810. godine. M. Kozličić, Istočni Jadran u djelu Beautemps-Beaupréa, 398.

41 Pomorska karta MK-26 Dubrovnik, Plan Cavtat.

42 Za razliku od suvremenih peljara, opći podatci prikazani su nakon uputa za plovidbu. Naime, u suvremenim peljarima obično se prvo navode opće upute i podatci, a zatim preciznije upute za plovidbu određenim plovidbenim područjima.

43 Iako su brodovi na mehanički pogon vremenom istisnuli jedrenjake te su se sukladno tomu i pomorske publikacije prilagođavale novim pomorskim tehnologijama, upute za plovidbu jedrenjacima mogu se naći čak i u nautičkim publikacijama sredine 20. stoljeća. Tako su u publikaciji Peljar po Jadranu, I. i II. dio iz 1952. odnosno iz 1953. godine, u izdanju Hidrografskog 
morskih struja je točna, što potvrđuje i karta površinskih morskih struja Jadrana u ljetnom i zimskom razdoblju. ${ }^{44}$ Upute također navode kako su morske struje uglavnom nepravilne i da ovise o morskim mijenama, snazi i smjeru vjetra. Od vjetrova spominje se Tramontane, odnosno $\mathrm{N}$ vjetar koji uzrokuje velike poteškoće u plovidbi, a pogotovo kod plovidbe u NW kursu koji vodi prema sjeveru Jadrana odnosno Veneciji. ${ }^{45}$

Upute za plovidbu navedene su od južnog ulaza u Jadran na zapadnoj obali, od Otranta prema sjeveru do Venecije, a zatim istočnom obalom prema jugu do izlaza iz Jadrana, odnosno rta Linguetta. Uobičajene plovidbene rute, a što je opisano u općim uputama, oduvijek su išle istočnom obalom, dok se zapadnom obalom ponekad plovilo prema izlazu iz Jadrana donekle slijedeći opći smjer morskih struja u Jadranu. ${ }^{46}$

Peljar ima i posebnu napomenu koja je vrlo zanimljiva, a odnosi se na kršenje autorskih prava. Naime, konkurentski izdavač pomorskih karata i publikacija Robert Blachford ${ }^{47}$ neovlašteno je kopirao prvo izdanje peljara, kao i još nekih karata i publikacija, te je u napomeni najavljeno kako će Laurie and Whittle poduzeti sve pravne akcije u svrhu zaštite intelektualnog vlasništva. ${ }^{48}$

instituta Jugoslavenske ratne mornarice navedene najpovoljnije rute za jedrenjake. Spomenuti peljari iz sredine 20. stoljeća savjetuju jedrenjacima plovidbu uz istočnu obalu Jadrana. „Kao opće pravilo za jedrenjake neka služi to, da se, bilo zimi ili ljeti, bilo u plovidbi NW ili SE rutom - a u ovom posljednjem slučaju usprkos protivnim strujama - treba uvijek držati blizu istočne obale." Peljar po Jadranu I. dio istočna obala, Split, 1952., 49. i Peljar po Jadranu II. dio zapadna obala, Split, 1953., $44-45$.

44 Riječ je o karti Površinske morske struje Jadrana u ljetnom i zimskom razdoblju (prema ZoreArmanda, 1967.) koja se nalazi u hrvatskom peljaru Peljar I. Jadransko more - istočna obala iz 2012. godine.

45 Laurie and Whittle's New Sailing Directions for the Mediterranean Sea, 73.

46 Preporučena plovidbena ruta istočnom obalom Jadrana ucrtana je i na pomorskoj karti $A$ New Chart of the Mediterranean Sea iz 1826. godine koju je izdao Richard Holmes Laurie. Pomorski muzej, Dubrovnik, A New Chart of the MEDITERRANEAN SEA, Comprehending the Coast from CAPE ST. MARY (IN PORTUGAL), TO CONSTANTINOPLE; and from RABAT IN AFRICA, TO ALEXANDRETTO, OR ISKENDEROON IN ASIA \& $c$. Reduced from the Late and Spanish and French Charts, made by Order of the respective GOVERNMENTS, With the recent Surveys of CAPTAIN W[illia]m H[enr]y SMYTH. R[oyal] N[avy], Capt[ai]n. F. Beaufort, R[oyal] N[avy] and other British Officers, William Henry Smyth, Francis Beaufort, 1826., Zbirka pomorskih i zemljopisnih karata i atlasa, inv. br. DUM PM 885.

47 Robert Blachford (1775. - cca 1852.), londonski izdavač pomorskih karata i publikacija irskog porijekla.

48 Laurie and Whittle's New Sailing Directions for the Mediterranean Sea, b.o.s. Ovo je još jedan u nizu primjera kako su se zbog velike potražnje (čak i neovlašteno) pretiskavale već objavljene pomorske karte i publikacije, bez potrebnih provjera vjerodostojnosti podataka. 


\section{THE NEW MEDITERRANEAN PILOT IZ 1817. GODINE}

The New Mediterranean Pilot je engleski peljar tiskan u Londonu 1817.godine. Autor peljara je John William Norie, ${ }^{49}$ a izdavač je J. W. Norie \& Co. ${ }^{50}$ Peljar sadrži 184 stranice s opisima i uputama za plovidbu Sredozemljem uključujući obale Francuske, Španjolske i Portugala od Ushanta do Gibraltara, Mletački zaljev (Jadransko more), Arhipelag (grčki otoci) i dio Crnog mora. Prilikom sastavljanja peljara korištene su izmjere i radovi sljedećih autora: Bretonniere, Mechain, Tofino, Zannoni, Galiano i drugih u službi Francuske, Španjolske i Italije. Također su korištena zapažanja i bilješke brojnih zapovjednika i časnika trgovačkih i ratnih brodova. ${ }^{51}$

Peljar se sastoji od 24 nenumerirana poglavlja od kojih se 16. poglavlje po redu naslova Adriatic Sea or Gulf of Venice odnosi na Jadran (str. 122 - 135). U prvom dijelu 16. poglavlja (str. 123 - 132) su upute za plovidbu Jadranom od rta Otranto do rta Linguetta, dok se drugi dio pod naslovom General Remarks for the Gulf of Venice (str. 132 - 135) odnosi na opće upute za plovidbu Jadranom. Iz navedenog je već po broju stranica vidljivo kako je cjelokupno područje Jadrana tiskano na nepunih 14 stranica i dalje nedovoljno obrađeno, s tim da su opće upute tiskane na nepune četiri stranice. Međutim, u odnosu na prethodno analizirani peljar iz 1811. godine, ukupni broj stranica cijelog peljara nešto je veći, a također je veći i broj stranica koje se odnose na Jadransko more.

$\mathrm{Za}$ razliku od spomenutog peljara iz 1811. godine, u ovome su peljaru navedene upute ne samo za plovidbu Sredozemljem nego i za plovidbu uz obale Francuske, Španjolske i Portugala na području od Ushanta do Gibraltara, kao i upute za plovidbu dijelom Crnog mora, ${ }^{52}$ uz napomenu da su dubine koje se navode u peljaru jednake dubinama na razini niske vode živih morskih mijena. ${ }^{53}$

49 John William Norie (1772. - 1843.), britanski matematičar, hidrograf i kartograf, autor nekoliko nautičkih priručnika i tablica. U njegova djela između ostalih spadaju Set of Nautical Tables iz 1803. godine, Tome of Practical Navigation iz 1805. godine i A Set of Lunar tables for correcting the apparent distance of the Moon from the Sun iz 1815. godine. Bibliotheca Britannica, Volume II., Edinburgh, 1824., $708-709$.

50 Autor peljara John William Norie ujedno je bio i vlasnik izdavačke tvrtke Norie \& Co. koja je tiskala pomorske karte i publikacije. Tvrtka Norie \& Co. naslijedila je tvrtku u vlasništvu Williama Heathera koja se bavila prodajom i servisiranjem navigacijskih instrumenata te tiskanjem i prodajom pomorskih karata i publikacija. Upravo je kod Williama Heathera John Norie i započeo svoju poslovnu karijeru. Norie, John William, u: Dictionary or National Biography,Vol. XLI., (ed. Sidney Lee), New York - London, 1895., 111 - 112.

51 John William Norie, The New Mediterranean Pilot, London, 1817., b.o.s.

52 Spomenuti dio Crnog mora zapravo je Mramorno more od Dardanela do Bospora, odnosno Istanbula.

53 J. W. Norie, The New Mediterranean Pilot, 1. 
Kursovi i azimuti u peljaru su magnetski što predstavlja razliku od peljara iz 1811. godine u kojem su kursovi i azimuti pravi. To u praksi znači kako će se kursovi i azimuti navedeni u ovome peljaru za nekoliko godina izmijeniti (ovisno o godišnjoj promjeni varijacije) te je potrebno imati točne podatke o magnetskoj varijaciji za područje plovidbe da bi se mogla izvršiti korektura za razdoblje proteklo od tiskanja peljara. Otežavajuća okolnost je i ta što peljar ne navodi vrijednosti varijacije na području Jadrana, nego samo postoji napomena kako varijacija na području Biskaja iznosi skoro dvije zrake (22030”) W..$^{54}$ Međutim, prema izmjerama kapetana Williama Henryja Smytha varijacija je 1819. godine na dubrovačkom području iznosila $16^{\circ} 00,0^{\prime} \mathrm{W}$, a na području otoka Mljeta $15^{\circ} 00,0^{\prime} \mathrm{W} . .^{55}$

Jadran je kao i u peljaru iz 1811. godine opisan od Otranta na zapadnoj obali nastavljajući sjeverno do Venecije te zatim prema jugu istočnom obalom sve do izlaza iz Jadrana na rtu Linguetta. Dubrovački akvatorij je u peljaru prikazan na stranici 131 u tri ulomka od kojih se jedan odnosi na otok Mljet, drugi na Elafitske otoke, a treći na Dubrovnik i Cavtat. Kao i prethodno analizirani peljar, tako i ovaj slijedi „obrnuti“ smjer plovidbe, stoga je otok Mljet prvo područje koje će se obraditi.

„Mljet (Melida) je dug otok koji se prostire u smjeru ESE $1 / 2$ S (magnetskom) i duljine je $71 \frac{1}{2}$ liga $(22,5 \mathrm{M})$, a širine $1 \frac{1}{2}$ lige (4,5 M). Zapadni kraj otoka Mljeta udaljen je 3 lige u smjeru S za E (magnetskom) od rta Ražnjić na otoku Korčuli. Između otoka Mljeta i poluotoka Pelješca je dobar kanal koji vodi prema Dubrovniku (Mljetski kanal) i u kojem nema zapreka za plovidbu. Međutim, treba se držati na većoj udaljenosti od sjeverne obale Mljeta zbog pličine koja se nalazi na $1 \frac{1}{2} \mathrm{M}$ od otoka Mljeta. Stoga, kod rta Ražnjić treba postaviti kurs prema obali Pelješca od koje se treba držati oko 1 ligu i tada brod neće biti u opasnosti. Na otoku Mljetu postoji nekoliko uvala i sidrišta koji su u slučaju potrebe prikladni za manja plovila. Najznačajnija su: luka Polače (Palazzo), uvala Križice (Crisi) i uvala Prožura (Chiave) na otoku Mljetu i Žuljana (Zuliana) na lijevoj obali kanala, odnosno na obali poluotoka Pelješca." ${ }^{\text {"6 } 6}$

54 J. W. Norie, The New Mediterranean Pilot, 1.

55 M. KozLičić, Istočni Jadran u djelu Beautemps-Beaupréa, 31.

56 „Melida is a long island lying in a E. S. E. $1 / 2$ southerly direction $71 \frac{1}{2}$ leagues, and $1 \frac{1}{2}$ league broad; its western Point bears from Cape Speo in Curzola S. by E. distant three leagues. Between these, and within this island and the Sabioncello shore is a good open Channel toward Ragusa; but you should give the northern part of the island a good birth, on account of a shoal about $1 \frac{1}{2}$ mile from the island. Sail therefore nearer Cape Speo, steering onward for the Sabioncello shore, keeping at the distance of about a league off, and you will meet with no danger whatever. There are several ports and places for anchorage about Melida, fitted for small vessels, if necessary to resort to them; of these Ports, Palazzo, Crisi, and Chiave, are the principal; there is also the Port of Zuliana on the larboard shore."J. W. Norie, The New Mediterranean Pilot, 131. 
Kao i u prethodnom peljaru iz 1811. godine, i ovdje nailazimo na uporabu lige kao mjerne jedinice. Prema peljaru smjer u kojem se prostire otok Mljet je otprilike $198^{\circ}-118^{\circ}$ što ispravljeno za najbližu poznatu varijaciju iz 1819 . godine daje približnu vrijednost $183^{\circ}-103^{\circ}$. Navedeno je prilično točno u usporedbi sa $190^{\circ}-110^{\circ}$ kako je približna orijentacija $\mathrm{N}$ obale Mljeta prema pomorskim kartama. ${ }^{57}$ Dimenzije otoka ponešto se razlikuju od onih u prethodnom peljaru. Primjerice, duljina otoka ima veće odstupanje od stvarne vrijednosti nego u peljaru iz 1811. godine te ono iznosi preko 2,5 M. Širina otoka, koja je u peljaru navedena kako iznosi $4,5 \mathrm{M}$, u stvarnosti na najširem dijelu otoka nije veća od $3 \mathrm{M}$, što je već značajnije odstupanje. Udaljenost od otoka Korčule navedena je točno, uz točan navod od kojih je točaka izvršeno mjerenje, što s prethodnim peljarom nije bio slučaj.

Za razliku od peljara iz 1811 . godine, ovdje se indirektno upućuje na plovidbu Mljetskim kanalom kojim se plovi prema Dubrovniku, odnosno danas prema dubrovačkoj luci Gruž. ${ }^{58}$ Kod plovidbe prema Dubrovniku se nakon izlaska iz Mljetskog kanala može nastaviti rutom kroz Koločepski kanal ili rutom s vanjske strane Elafitskih otoka. Navod o postojanju pličine zbog koje se treba držati podalje od sjeverne obale Mljeta je netočan, jer prema pomorskim kartama u Mljetskom kanalu ne postoji nikakva pličina na udaljenosti od 1,5 M od Mljeta. ${ }^{59}$ Spomenuta zakloništa Polače, ${ }^{60}$ Križice, Prožura ${ }^{61}$ i Žuljana ${ }^{62}$ uistinu su pogodna za manja plovila, s tim da je od navedenih uvala Polače najzaklonjenija i može

57 Također bi trebalo uzeti u obzir i mogućnost kako su podatci o varijaciji s kojom su ispravljani kursovi u peljaru vjerojatno nekoliko godina stariji od godine izdanja peljara te su moguća i još veća odstupanja.

58 Mljetski kanal je prolaz između poluotoka Pelješca i otoka Mljeta i plovan je za sve brodove. Peljar I. Jadransko more - istočna obala, 267.

59 Spomenuta pličina na udaljenosti od približno 1,5 M od NW kraja otoka Mljeta prikazana je na pomorskoj karti područja Dubrovačke Republike Vincenza di Lucija. Pomorski muzej, Dubrovnik, Pomorska karta područja Dubrovačke Republike. Međutim, na pomorskim kartama iz druge polovice 19. stoljeća ne postoji nikakva pličina koja bi odgovarala spomenutim navodima, kao što je primjerice prikazano na pomorskoj karti otoka Mljeta u izdanju Hidrografskog zavoda c. i kr Ratne mornarice Austro-Ugarske Monarhije iz 1879. godine (autor: Tobias Oesterreicher). Pomorski muzej, Dubrovnik, Meleda, Tobias Oesterreicher, 1879., Zbirka pomorskih i zemljopisnih karata i atlasa, inv. br. DUM PM 990.

60 Luka Polače je prostrana uvala na sjevernoj obali otoka Mljeta između rtova Stupa i Križice, a zaštićena je otočićima Kobrava, Ovrat, Tajnik i Moračnik. Luka Polače ujedno je i pristanište za naselje Goveđari. Peljar I. Jadransko more - istočna obala, 269. Za jedrenjake koji uplovljavaju u luku Polače najpovoljniji prilaz je južno od otočića Kobrave. Peljar po Jadranu I. dio istočna obala, 394.

61 Uvala Prožura zaklonjena je od svih vjetrova osim od bure i NW vjetrova koji stvaraju umjerene valove. Peljar I. Jadransko more - istočna obala, 268.

62 Žuljana je mala luka u istočnom dijelu zatona Žuljana i zaštićena je od svih vjetrova, ali je izložena valovima koje stvaraju SW i NW vjetrovi. Peljar I. Jadransko more - istočna obala, 267. 


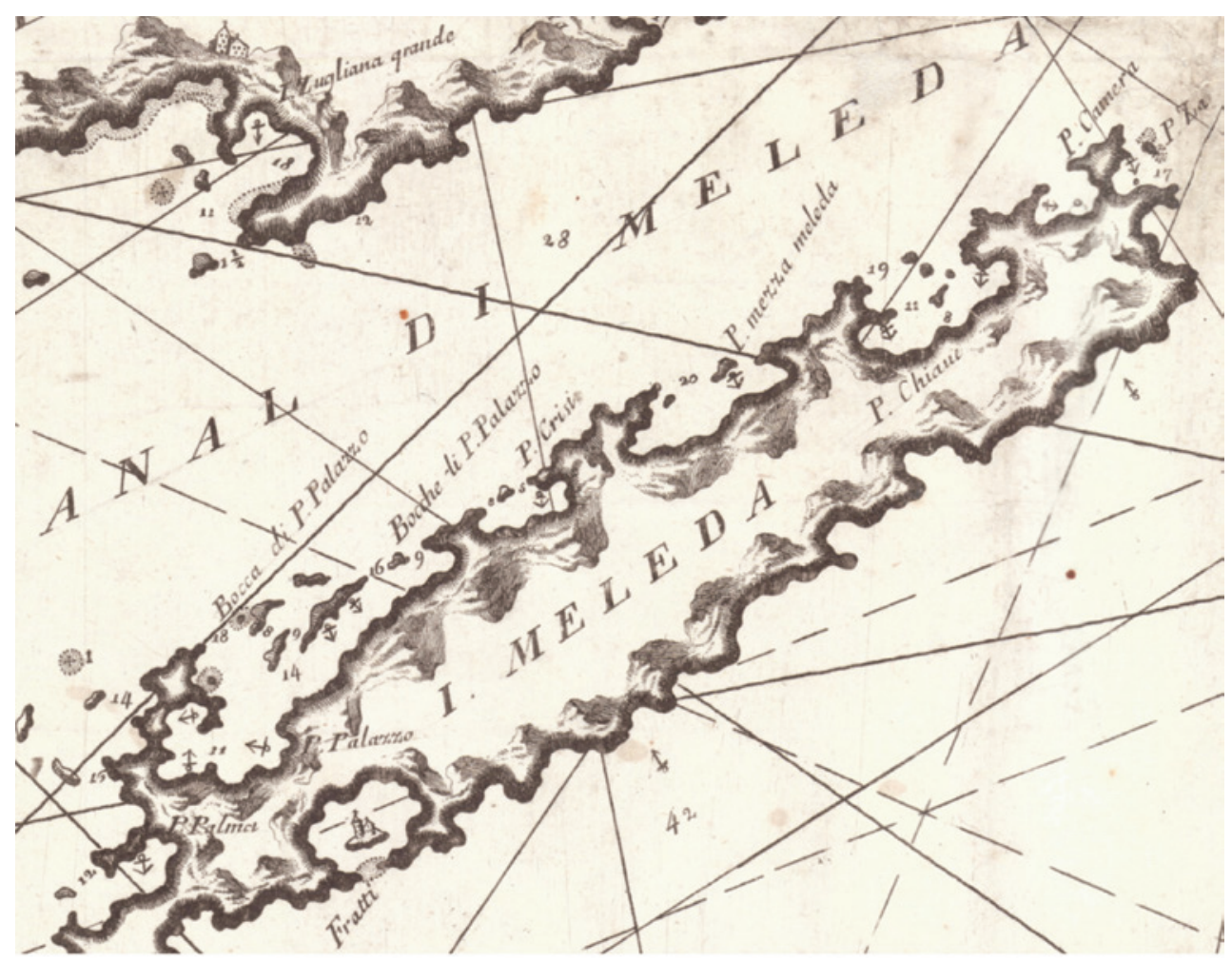

SLIKA 3. Isječak pomorske karte područja Dubrovačke Republike autora Vincenza di Lucia na kojem su prikazana sidrišta na otoku Mljetu, kao i sidrište Žuljana na poluotoku Pelješcu (Izvor: Pomorski muzej, Dubrovnik, Pomorska karta područja Dubrovačke Republike, Vincenzo di Lucio, ca. 1800., Zbirka pomorskih i zemljopisnih karata i atlasa, inv. br. DUM PM 227.)

primiti i nešto veća plovila. ${ }^{63}$ Iako je kao zaklonište pogodna za manje brodove, uvala Križice u hrvatskom peljaru iz 2012. godine nije navedena kao sidrište, jer ona nalazi na području Nacionalnog parka Mljet te je u njoj sidrenje zabranjeno. ${ }^{64}$ Međutim, na pomorskoj karti područja Dubrovačke Republike Vincenza di Lucia (Slika 3) uvala Križice (P. Crisi) je uz ostala navedena zakloništa također označena

63 Veći brodovi mogu se zakloniti od svih vjetrova u uvali Pomena i uvali Luka Polače, dok se manji brodovi mogu zakloniti od svih vjetrova osim bure u lukama Sobra, Prožura i Podškolj. Peljar I. Jadransko more - istočna obala, 268 - 269. Iako su uvale Pomena i Polače sigurna sidrišta, jedrenjacima je otežano uplovljavanje u obje uvale. Peljar po Jadranu I. dio istočna obala, 391. Navedena zakloništa i danas koriste brojne jahte i brodice, koje svojim dimenzijama odgovaraju brodovima iz razdoblja peljara, a najposjećenije od njih je sidrište Polače koje se nalazi na području Nacionalnog parka Mljet.

64 Peljar I. Jadransko more - istočna obala, Prilog, 6. 
kao sidrište. ${ }^{65}$ Ujedno peljar iz 1817. godine ne spominje luku Sobra koja je u prethodnom peljaru iz 1811. godine bila jedina navedena kao moguće zaklonište na otoku Mljetu, a koja je kao i ostala zakloništa prikazana i na di Luciovoj karti.

„Nakon što se prođe istočni kraj otoka Mljeta (Melida), uočit će se nekoliko otoka koji se protežu uz obale dubrovačkog kopna. Između navedenih otoka su prolazi, koji su ujedno i dobra sidrišta, a najbolja od njih su iza otoka Lopud (Mezzo) i Koločep (Calamota). U prolazu između otoka Lopuda i otoka Koločepa točno na sredini prolaza nalazi se podvodni greben. Dubine sa svake strane grebena su 16 - 19 hvati $(29,3-34,7 \mathrm{~m})$, stoga treba izbjegavati plovidbu sredinom prolaza te se držati obala otoka kako bi sigurno prošli.“" ${ }^{66}$

Otoci navedeni u peljaru su Elafitski otoci, i to od zapada prema istoku: Olipa, Jakljan, Šipan, Lopud i Koločep, koji se nalaze u liniji i formiraju Koločepski kanal, a između kojih su spomenuti prolazi i sidrišta. Izvan navedene skupine otoka su još i otočić Daksa koji se nalazi ispred ulaza u luku Gruž, otočić Sveti Andrija koji je izdvojen prema otvorenom moru te skupina hridi zvana Grebeni istočno od Koločepa. Podvodni greben u prolazu između otoka Lopud i Koločep odnosno u Koločepskim vratima je pličina Čavalika $(3,5 \mathrm{~m})$. Spomenuta pličina ne nalazi se točno na sredini prolaza kako stoji u peljaru, ali su dubine ispravno navedene. ${ }^{67} \mathrm{U}$ peljaru međutim nisu navedene ostale opasnosti za plovidbu zbog kojih se i ne preporučuje plovidba Koločepskim vratima noću, a to su kameniti otočić Veliki Skupio i pličina Tumbajica $(5,8 \mathrm{~m})$ istočno od otočića ${ }^{68}$

„Udaljenost od Mljeta do Dubrovnika je 5 liga $(15 \mathrm{M})$. Ispred Dubrovačkog zaljeva (Bay of Ragusa) su 4 otoka koji su međusobno prilično udaljeni, a između njih su prolazi u kojima je more duboko. Na otočiću najbližem Dubrovniku nalazi se crkvica (kapela) svetog Marka. Dubrovnik je prepoznatljiv po građevini koja se nalazi na brdu iznad grada. Na suprotnoj strani zaljeva je Cavtat (old Town of Ragusa) ispred kojega je dobro sidrište dubine 6 - 8 hvati (11 - 14,6 $\mathrm{m})$. Iza Cavtata je uvala gdje su dubine nešto manje, ali brodovi svejedno sidre na 3 hvata $(5,5 \mathrm{~m})$. Nasuprot ulazu u luku Cavtat nalazi se jedan podvodni greben (pličina Seka Velika), a drugi je kod E rta na ulazu (pličina Seka Mala). SE od

65 Pomorski muzej, Dubrovnik, Pomorska karta područja Dubrovačke Republike.

66 „Having passed the eastern end of Melida, you will perceive several islands which lie before the main land of Ragusa. Between each of these islands there are good channels, and places fit for anchoring in, but more particularly behind the Mezzo and Calamota. In the channel between these two islands is a rock under water, lying directly in the middle of the passage; on each side are from 16 to 19 fathoms: therefore in passing, avoid mid-channel, and sail near the islands, by which you will readily pass in safety."J. W. NORIE, The New Mediterranean Pilot, 131.

67 Pomorska karta MK-26 Dubrovnik.

68 Peljar I. Jadransko more - istočna obala, 274. 
unutrašnjeg otoka (Supetar) nalazi se još jedan podvodni greben (hrid Šuperka), tako da je kod plovidbe prema mjestu Srebreno (Town of Verdura) potreban oprez. U Dubrovačkom zaljevu inače nema skrivenih opasnosti za plovidbu, ali je zaljev izložen SE vjetrovima. 34 M SE od Dubrovnika je rt Oštra (Point Rapata) odnosno zapadni rt na ulazu u Boku kotorsku koja je ušće velike rijeke i nije plovna dalje od Kotora." ${ }^{\text {"69 }}$

Peljar navodi da je udaljenost od Mljeta do Dubrovnika 15 M, što je približno točno, jer je prema karti udaljenost od rta Debeli do dubrovačke stare gradske luke otprilike 16,2 M. Kao i u prethodnom peljaru iz 1811. godine, tako se i u ovom peljaru koristi hidronim Bay of Ragusa, odnosno Dubrovački zaljev, pod kojim se podrazumijeva područje koje obuhvaća Župski zaljev i Lokrumski prolaz, s Dubrovnikom i Cavtatom na krajevima zaljeva. Četiri otoka u spomenutom zaljevu također se spominju i u prethodnom peljaru, a to su otoci Lokrum, Mrkan, Bobara i Supetar, koji i jesu međusobno prilično udaljeni. Još jedan podatak koji je istovjetan peljaru iz 1811. godine odnosi se na navod po kojem se na otoku koji je najbliži Dubrovniku (point of Ragusa), a to je otok Lokrum, nalazi crkvica (kapela) svetog Marka. Kao što je već spomenuto, na Lokrumu ne postoji vjerski objekt posvećen svetom Marku, ali kapetan William Henry Smyth spominje utvrdu Sveti $\mathrm{Marko}^{70}$ na Lokrumu čija je pozicija 42³7’40” N 1806’54” E, i uz

69 „RAGUSA. - From Melida to Ragusa is 5 leagues. Before the Bay of Ragusa lie four Islands at some distance from each other, having deep water channels between them; that nearest Ragusa Point has a small chapel dedicated to 8 t. Mark upon it. Ragusa is well known by a building standing upon a mountain above the city: on the opposite side of the Bay is the old Town of Ragusa, before which is good anchorage in 6 or 8 fathoms. There is also a cove beyond it, with less water, where a vessel may ride in 3 fathoms. Directly opposite to the entrance to the old Port is a rock under water, and near the eastern Point of the old Port is another; there is also a sunken rock lying S. E. of the inner island: in taking, therefore, this passage, toward the Town of Verdura, great caution is requisite; the Bay of Ragusa is otherwise safe and clear from dangers, though open to the S. E. winds. S. E. from Ragusa about 34 miles is Point Rapata, the western Point of the Bay of Cattaro; - this is the mouth of a considerable river, but not navigable beyond the Town of Cattaro." J. W. NoRIE, The New Mediterranean Pilot, 131.

70 Lacroma i San Marco su toponimi koje je koristio Beautemps-Beaupré prilikom kartografiranja dubrovačkog područja i odnose se na otok Lokrum, kao primjerice na plovidbenoj karti Dubrovačkog akvatorija Zaton - Cavtat iz 1820. godine. M. Kozličić, Istočni Jadran u djelu Beautemps-Beaupréa, 406. Spomenute toponime koristili su i Englezi, pa je tako na engleskoj pomorskoj karti iz 1844. godine (na kojoj se nalaze Beautemps-Beaupréovi planovi Gruža, Dubrovnika i Cavtata nastali 1820. godine) utvrda Royal na Lokrumu nazvana Fort San Marco. Spomenuta karta iz 1844. godine temeljila se na hidrografskim istraživanja kapetana Williama Henryja Smytha. M. KozLIČIć, Istočni Jadran u djelu Beautemps-Beaupréa, 415. Vjerojatno je da su ti toponimi preuzeti od Vincenza di Lucija jer je njegova karta bila tiskana i često upotrebljavana. Na spomenutoj karti Vincenzo di Lucio također za Lokrum navodi ime S. Marco. Pomorski muzej, Dubrovnik, Pomorska karta područja Dubrovačke Republike. 


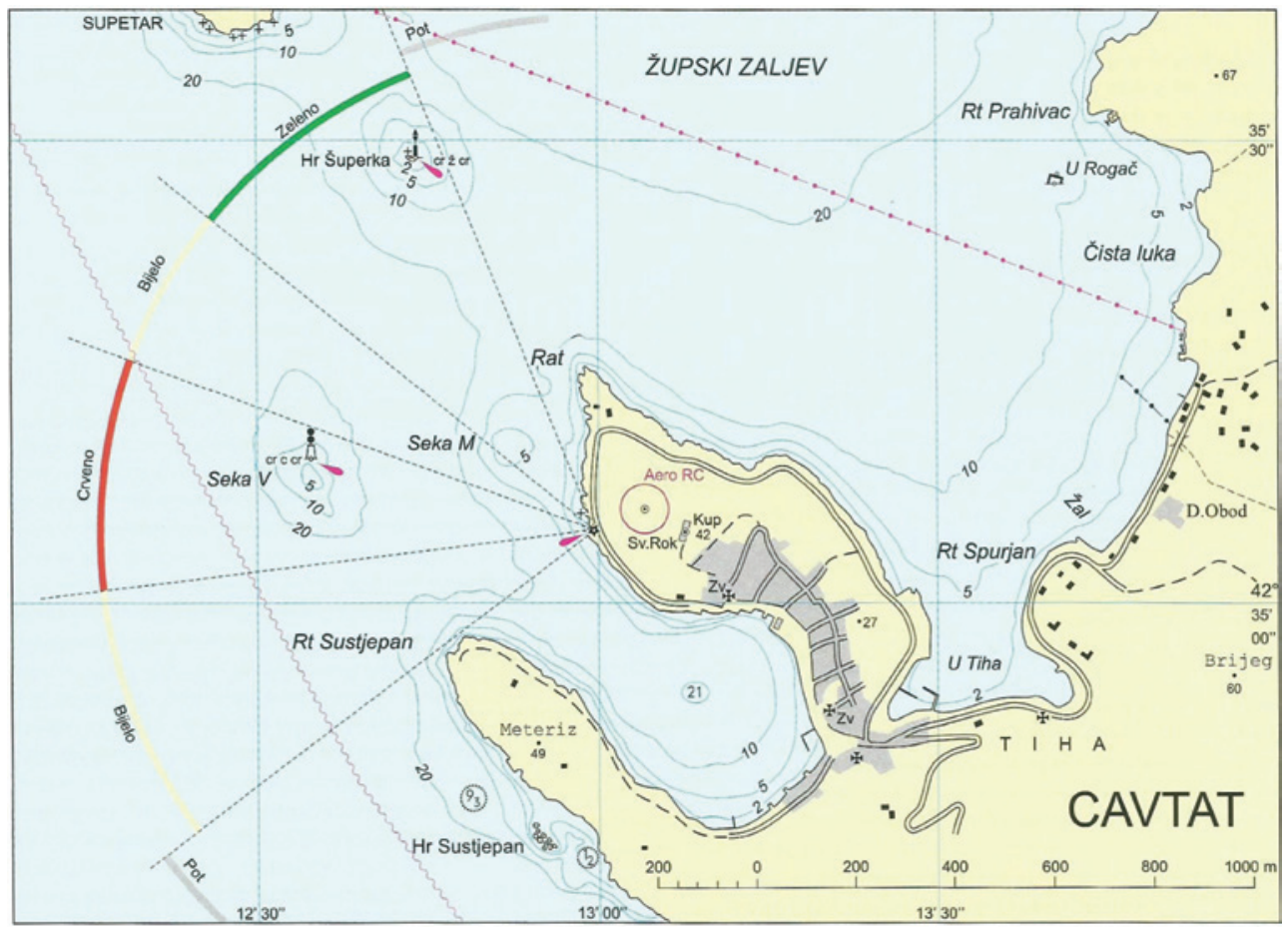

SLIKA 4. Cavtat (Izvor: Peljar I. Jadransko more - istočna obala, Split, 2012., 287.)

koju stoji podatak iz 1819 . godine o varijaciji od $16^{\circ}(\mathrm{W}) .{ }^{71}$ Navedena pozicija uz mala odstupanja odgovara stvarnoj poziciji utvrde Fort Royal na Lokrumu čija je gradnja započeta za francuske uprave 1808. godine i koja je nadograđivana 1833. godine, tijekom razdoblja austrijske uprave. ${ }^{72}$

Za pretpostaviti je kako je autor peljara pod građevinom na brdu iznad Dubrovnika (brdo Srd) smatrao utvrdu Imperijal izgrađenu u razdoblju francuske uprave (1806. - 1810.), a ne crkvu svetog Srđa koja je pri tome bila srušena. ${ }^{73}$ Cavtat se kao i u prethodnom peljaru naziva old Town of Ragusa te se spominje i sidrište za koje su dubine točno navedene. ${ }^{74} \mathrm{Za}$ razliku od prethodnog peljara, kao moguće sidrište spominje se još i uvala kod Cavtata odnosno uvala Tiha, za koju su dubine također točne. ${ }^{75}$ Danas oba sidrišta koriste jahte i brodice od kojih neke

71 William Henry Smyth, The Mediterranean, London, 1854., 449.

72 S. Piplović, Graditeljstvo u Dalmaciji za francuske uprave, 87.

73 Crkva Svetog Srđa kao orijentir ponovo će biti spomenuta u sljedećem analiziranom peljaru iz 1826. godine.

74 Pomorska karta MK-26 Dubrovnik, Plan Cavtat.

75 Pomorska karta MK-26 Dubrovnik, Plan Cavtat. 
svojim dimenzijama čak i nadmašuju plovila iz razdoblja u kojem je tiskan peljar. U peljaru su navedene i opasnosti za plovidbu u blizini Cavtata, a to su hrid Šuperka te pličine Seka Velika i Seka Mala. Opisi i pozicije navedenih opasnosti prilično su pouzdani s obzirom na to da potvrđuju plan Cavtata (Slika 4) te opis Cavtata iz hrvatskog peljara Peljar I. Jadransko more - istočna obala izdanog 2012. godine. ${ }^{76}$

Nakon Cavtata peljar nastavlja s opisom obale prema jugu odnosno Boki kotorskoj. Rt Oštra spominje se kao zapadni kraj ulaza u Boku kotorsku, međutim udaljenost od $34 \mathrm{M}$ između Dubrovnika i rta Oštra je pogrešna jer je stvarna udaljenost $24 \mathrm{M}$, što je ipak znatno odstupanje. Zanimljiva je i činjenica da autor peljara smatra kako je Boka kotorska ušće rijeke. ${ }^{77}$

Drugi dio poglavlja (str. 132 - 135) pod naslovom General Remarks for the Gulfof Venice odnosi se na opće upute za plovidbu obzirom na vjetrove i morske struje te njihovu povezanost. Upute savjetuju plovidbu istočnom obalom Jadrana u kursu NW za N (magnetskom), s obzirom na to da su uz zapadnu obalu struje pretežito južnog smjera, a tramontana ili sjeverni vjetrovi pušu takvom snagom da se ne bi moglo ploviti dalje od brda St. Angelo, odnosno područja Gargana. Detaljno je opisana i ruta kojom treba ploviti prema Veneciji. Podatci o strujama većim su dijelom temeljeni na zapažanjima venecijanskog peljara Vincenza di Lucia. ${ }^{78}$ Općenito se za struje u Jadranu navodi kako su one južnog smjera i da su toliko nepravilne i promjenjive i potrebno je znatno iskustvo kako bi se ustanovilo njihovo djelovanje i učinak. Uz istočnu obalu Jadrana struje su uglavnom sjevernog smjera, osim u prolazima između otoka, i brzine su oko 1 čv, a njihovo djelovanje osjetno je sve do udaljenosti oko $30 \mathrm{M}$ od talijanske obale. Pri tome su podložne utjecajima vjetra i morskih mijena te se sukladno tomu mijenja smjer i brzina struje. Detaljno je opisano i djelovanje morskih struja s obzirom na doba godine odnosno prema mjesecima, kao i utjecaj vremenskih prilika na morske struje. ${ }^{79}$

76 Cavtat je dobro zaštićena luka smještena u uvalici između rtova Sustjepan i Rat. Potpuno je zaštićen od juga, bura ne puše jako, a jaki W i NW vjetrovi uzrokuju valovito i jače valovito more. Tijekom SW, W i NW vjetrova najbolje je sidriti uz obalu poluotoka Sustjepan u SW dijelu luke gdje dno dobro drži. Ispred ulaza u luku treba paziti na pličine Seka velika (3,7 m) i Seka mala (3 m). Peljar I. Jadransko more - istočna obala, 286 - 288.

77 Budući da je u peljaru navedeno kako spomenuta rijeka nije plovna dalje od Kotora, za pretpostaviti je kako autor peljara smatra da je riječ o rijeci Škurdi na čijem se ušću nalazi Kotor.

78 Vincenzo di Lucio je 1798. godine u Veneciji objavio brošuru Trattato delle correnti del golfo Adriatico u kojoj opisuje morske struje na Jadranu. Englesko izdanje spomenute brošure na 25 stranica pod naslovom Treatise on the Currents in the Gulf of Venice 1806. godine u Londonu tiskao je William Bulmer \& Co, za W Fadena. Vincenzo di Lucio Treatise on the Currents in the Gulfof Venice, https:// discovery .nationalarchives.gov.uk/details/r/C8868901, (posjećeno 10.9. 2020.). 
Peljar iz 1817. godine je u odnosu na prethodni iz 1811. godine nešto većeg opsega (gledano po broju stranica), i to ne samo za područje Sredozemlja, već i za cijeli Jadran. Što se tiče Jadrana, najveći pomak u kvantiteti i kvaliteti informacija očituje se u općem dijelu, gdje je detaljno opisano djelovanje morskih struja. Međutim, količina informacija za dubrovačko područje i dalje je vrlo mala, iako su same informacije nešto opsežnije i pouzdanije nego u prethodnom peljaru.

THE NEW SAILING DIRECTORY FOR THE MEDITERRANEAN SEA, THE ADRIATIC SEA OR THE GULF OF VENICE, THE ARCHIPELAGO AND LEVANT, THE SEA OF MARMARA AND THE BLACK SEA IZ 1826.

Ovo je engleski peljar iz 1826. godine u izdanju Richarda Holmesa Laurieja, ${ }^{80}$ ovlaštenog agenta i distributera Britanskog admiraliteta. Sadrži 360 stranica s opisima i uputama za plovidbu Sredozemljem uključujući Mletački zaljev (Jadransko more), Arhipelag, Levant, Mramorno i Crno More i najopsežniji je od sva tri analizirana peljara.

Peljar je sastavio John Purdy, ${ }^{81}$ i to, kako se navodi, iz brojnih javnih i privatnih izvora te izvodeći zaključke iz provjerenih činjenica koje nisu općepoznate i koristeći radove Beauforta, Smytha, ${ }^{82}$ Von Zacha, ${ }^{83}$ Tofina i mnogih drugih

80 Kao što je već spomenuto, izdavač Richard Holmes Laurie bio je sin Roberta Laurieja koji je nakon smrti Jamesa Whittlea 1818. godine postao jedini vlasnik tvrtke Whittle and Laurie (prije Laurie and Whittle) te je nastavio poslovanje pod imenom Richard Holmes Laurie. Laurie, Robert, u: Dictionary or National Biography, Vol. XXXII., 211.

81 John Purdy (1773. - 1843.), britanski hidrograf, autor nekoliko nautičkih priručnika i tablica. Sin trgovca knjigama iz Norwicha od rane mladosti posvetio se proučavanju pomorskih karata i publikacija. Oko 1812. godine u izdavačkoj tvrtki Laurie \& Whittle koja se bavila izdavanjem pomorskih karata i publikacija naslijedio je dotadašnjeg hidrografa De la Rochettea. Iako osobno nije vršio izmjere na terenu, već je svoje radove temeljio na korištenju postojećih i dostupnih izmjera, John Purdy postaje jedan od vodećih hidrografskih autoriteta svog vremena. Purdy, John, u: Dictionary or National Biography Vol. XLVII., (ed. Sidney Lee), New York - London, 1896.,46.

82 Willian Henry Smyth (1788. - 1865.), britanski astronom i hidrograf. Svoju bogatu hidrografsku karijeru započeo je 1810. godine kada je preuzeo zapovjedništvo nad španjolskim brodom Mors aut Gloria. Na početku karijere svoje djelovanje temeljio je na radovima Don Vincentea Tofiña, odnosno njegovu djelu Atlas Maritimo de España. Smythove hidrografske aktivnosti na Jadranu započinju 1818. godine kada je dogovorio provođenje zajedničkih englesko-austrijsko-napuljskih izmjera, a koje su pod njegovim vodstvom završene do kraja 1819. godine. Andrew DAvid, British Hydrographic Surveys in the Mediterranean in the early years of the Nineteenth Century, International Hydrographic Review, 6 (3), Monaco, 2005., 10 - 24.

83 Riječ je o Antonu Freiherru Von Zachu, bratu čuvenog astronoma Franza Xavera Von Zacha. Anton Von Zach je od 1816. godine vršio izmjere istočne obale Jadrana i ostvario značajan napredak prije nego što je kapetan Smyth krenuo sa svojim istraživanjima. W. H. SMYTH, The Mediterranean, 363. 


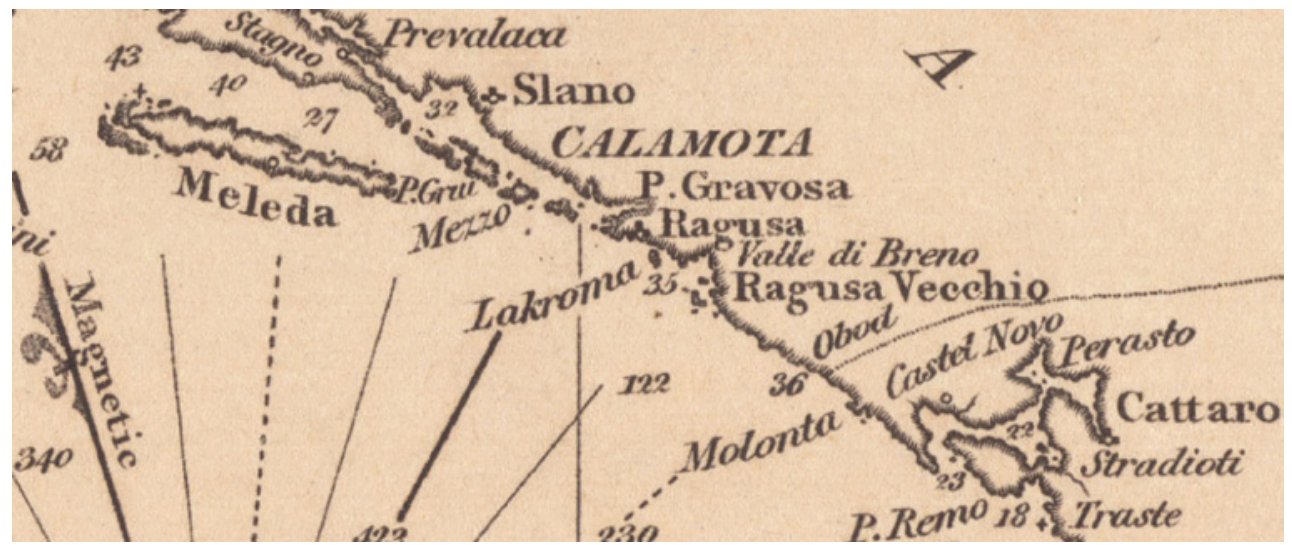

Slika 5. Isječak pomorske karte $A$ New Chart of the Mediterranean Sea u izdanju Richarda Holmesa Laurieja iz 1826. godine na kojem je prikazano područje od otoka Mljeta do Boke kotorske (Izvor: Pomorski muzej, Dubrovnik, A New Chart of the MEDITERRANEAN SEA, Comprehending the Coast from CAPE ST. MARY (IN PORTUGAL), TO CONSTANTINOPLE; and from RABAT IN AFRICA, TO ALEXANDRETTO, OR ISKENDEROON IN ASIA \& c. Reduced from the Late and Spanish and French Charts, made by Order of the respective GOVERNMENTS, With the recent Surveys of CAPTAIN W[illia]m H[enr]y SMYTH. R[oyal] $N$ [avy], Capt[ai]n. F. Beaufort, R[oyal] N[avy] and other British Officers, William Henry Smyth, Francis Beaufort, 1826., Zbirka pomorskih i zemljopisnih karata i atlasa, inv. br. DUM PM 885.)

autora. Upravo su izmjere poznatog engleskog hidrografa i astronoma, kapetana (kasnije i admirala) Williama Henryja Smytha bile vrlo kvalitetne i značajne za izradu pomorskih karata i publikacija ne samo Jadrana već i Sredozemlja u cijelosti. ${ }^{84}$ Početkom 19. stoljeća vladalo je mišljenje kako su karte istočne obale Jadrana vrlo neprecizne i loše te je Smyth uočio potrebu za detaljnim izmjerama i izradom preciznijih karata. ${ }^{85}$

Upravo je prema izmjerama Williama Henryja Smytha izrađena i generalna karta Sredozemlja $A$ New Chart of the Mediterranean Sea u izdanju Richarda Holmesa Laurieja iz 1826. godine, iste godine kada je spomenuti izdavač tiskao i peljar za područje Sredozemlja. Navedena karta ujedno je i prva generalna

84 Kapetan Smyth svojedobno je spominjao kako su rezultati izmjera Beautemps-Beaupréa koje je smatrao iznimno kvalitetno provedenima njemu dugo vremena bili nepoznati. Naime, rezultati spominjanih Beautemps-Beaupréovih izmjera Jadrana tek su 1849. godine postali dostupni široj javnosti

85 Tadašnju situaciju vezanu za pomorske karte i publikacije Jadranskog mora, kao i svoje sudjelovanje $\mathrm{u}$ hidrografskim izmjerama Jadrana, Smyth je opisao u svojoj knjizi The Mediterranean koja je tiskana 1854. godine u Londonu u izdanju John W. Parker and Sona. 
karta Mediterana čija je izrada utemeljena na znanstvenim izmjerama. Na Slici 5 prikazan je isječak spomenute karte koji prikazuje dubrovački akvatorij od otoka Mljeta do rta Oštra, uključujući i Boku kotorsku.

Upute za plovidbu podijeljene su na 22 poglavlja (Sections) numerirana od I do XXII. Poglavlje X pod naslovom „The Adriatic Sea or Gulf of Venice; including the Southern Coast of Italy, from Cape Spartivento" odnosi se na Jadran i obuhvaća stranice 168 - 193. U odnosu na prethodna dva peljara vidljivo je znatno povećanje broja stranica posvećenih plovidbi Jadranom.

Koordinate u peljaru (geografska širina i dužina) su prema Greenwichu. Kursovi i azimuti su kompasni ako nije posebno naznačeno, a kursovi i azimuti koji su napisani u zagradama - primjerice [WSW], su pravi. Drugim riječima, u ovome se peljaru primjenjuje kombinacija metode označavanja kursova i azimuta iz prethodna dva peljara. Između ostaloga, u peljaru je navedeno kako je tadašnja vrijednost varijacije za područje Trsta $17^{\circ} 30^{\prime} \mathrm{W}$, a za područja Brindisija i Krfa je $15^{\circ} \mathrm{W}$, stoga je varijacija za dubrovačko područje između navedenih vrijednosti. ${ }^{86}$ Varijacija je ustanovljena prema izvještajima $s$ ratnih brodova britanske Kraljevske mornarice stacioniranih u Sredozemlju. Smjerovi vjetrova, struja i morskih mijena koji su navedeni u peljaru su pravi. ${ }^{87}$

Prvi dio poglavlja X koje se odnosi na Jadran (str. 168 - 188) sadrži upute za plovidbu Jadranom, ali počevši od rta Spartivento, a ne od Otranta kao što je to u prethodno analiziranim peljarima do rta Linguetta. Upute za plovidbu podijeljene su u tri podnaslova („The Coasts of Lombardy, \&c.“, „The Coast of Istria from the Promontory Point to Trieste“, „The Eastern Coasts of the Adriatic, from Istria to Greece"), dok se četvrti podnaslov „General Remarks on, and Directions for, the Adriatic Sea“ (str. 188 - 193.) odnosi na opće upute za plovidbu Jadranom. Iz navedenog je već po broju stranica vidljivo kako je cjelokupno područje Jadrana detaljnije obrađeno nego u prethodna dva peljara.

Peljar se od prethodnih razlikuje i po tome što ima tablicu s geografskim pozicijama važnijih objekata koji se navode u peljaru, s napomenom kako se geografska dužina računa prema Greenwichu. Tablica se nalazi na početku

86 Prema pomorskoj karti $A$ New Chart of the Mediterranean Sea iz 1826. godine magnetska varijacija na području Jadrana je iznosila 16030' W. Pomorski muzej, Dubrovnik, A New Chart of the MEDITERRANEAN SEA, Comprehending the Coast from CAPE ST. MARY (IN PORTUGAL), TO CONSTANTINOPLE; and from RABAT IN AFRICA, TO ALEXANDRETTO, OR ISKENDEROON IN ASIA \& $c$. Reduced from the Late and Spanish and French Charts, made by Order of the respective GOVERNMENTS, With the recent Surveys of CAPTAIN W[illia]m H[enr]y SMYTH. R[oyal] N[avy], Capt[ai]n. F. Beaufort, R[oyal] N[avy] and other British Officers.

87 John Purdy, The New Sailing Directory for the Mediterranean Sea, the Adriatic Sea or the Gulf of Venice, the Archipelago and Levant, the Sea of Marmara and the Black Sea, London, 1826., 1. 
TABlica 1. Geografske pozicije objekata u dubrovačkom akvatoriju od rta Vratnik do rta Oštra s okolnim otocima uključujući otok Mljet, zabilježenih u engleskom peljaru The New Sailing Directory for the Mediterranean Sea, the Adriatic Sea or the Gulf of Venice, the Archipelago and Levant, the Sea of Marmara and the Black Sea iz 1826. godine

\begin{tabular}{|l|c|c|}
\hline \multicolumn{1}{|c|}{ Objekt } & geografska širina (N) & $\begin{array}{c}\text { geografska dužina } \\
\text { (E) }\end{array}$ \\
\hline Ston, utvrda na Supavi & $42^{\circ} 50^{\prime} 05^{\prime \prime}$ & $17^{\circ} 42^{\prime} 31^{\prime \prime}$ \\
\hline Slano, zvonik & $42^{\circ} 47^{\prime} 03^{\prime \prime}$ & $17^{\circ} 53^{\prime} 56^{\prime \prime}$ \\
\hline otok Mljet - luka Polače, palača & $42^{\circ} 47^{\prime} 06^{\prime \prime}$ & $17^{\circ} 22^{\prime} 50^{\prime \prime}$ \\
\hline otok Mljet - Rt Gruj ili istočni kraj brda Planjak & $42^{\circ} 42^{\prime} 16^{\prime \prime}$ & $17^{\circ} 43^{\prime} 10^{\prime \prime}$ \\
\hline Dubrovnik, utvrda na gatu & $42^{\circ} 38^{\prime} 18^{\prime \prime}$ & $18^{\circ} 06^{\prime} 54^{\prime \prime}$ \\
\hline otočić Mrkan, signal na uzvisini & $42^{\circ} 34^{\prime} 15^{\prime \prime}$ & $18^{\circ} 11^{\prime} 58^{\prime \prime}$ \\
\hline Molunat, carinarnica & $42^{\circ} 27^{\prime} 07^{\prime \prime}$ & $18^{\circ} 25^{\prime} 43^{\prime \prime}$ \\
\hline Rt oštra, ulaz u Boku kotorsku, signal & $42^{\circ} 23^{\prime} 28^{\prime \prime}$ & $18^{\circ} 32^{\prime} 04^{\prime \prime}$ \\
\hline
\end{tabular}

(Izvor: John PURDy, The New Sailing Directory for the Mediterranean Sea, the Adriatic Sea or the Gulf of Venice, the Archipelago and Levant, the Sea of Marmara and the Black Sea, London, 1826., XVII.)

publikacije, odmah iza sadržaja na stranicama ix - xxvii. Geografske koordinate objekata koji se nalaze na području analiziranom u radu prikazane su u Tablici 1.

Dubrovački akvatorij koji je analiziran u radu u peljaru je prikazan na stranicama 185 i 186 u tri ulomka, od kojih se prvi odnosi na otok Mljet, a druga dva na Dubrovnik i Cavtat. Kao i prethodna dva analizirana peljara, tako i ovaj slijedi „obrnuti“ smjer, te je otok Mljet prvo područje koje će se analizirati.

„Otok Mljet (ant. Melita) koji je u prošlosti pripadao Dubrovačkoj Republici nalazi se 3 lige SE od otoka Korčule i $5 \mathrm{M}$ od obale poluotoka Pelješca. Dug je 20 $\mathrm{M}$, a prosječne širine oko $1 / 2$ lige. Otok je brdovit, šarolikog izgleda i na njemu se nalazi nekoliko naselja. Na zapadnom kraju otoka nalazi se vrh Grabova glava (Mount Grabor), a na istočnom vrh Gradac (Mount Gradatz). Na istočnom kraju je i otočić Badanj (Mesa islet) iza kojeg se brodovi mogu zakloniti od svih vjetrova." 88

Kao i u prethodno analiziranim peljarima, i u ovom peljaru korištena je liga kao mjerna jedinica, ali su, za razliku od prethodnih peljara, sve udaljenosti točno

„MELEDA, [ant Melita] which formerly belonged to the republic of Ragusa, is three leagues to the south-eastward of Corzola, and 5 miles from the coast of Sabioncello. It is 20 miles in length, with a mean breadth of half a league. The island is mountainous, variegated, and has several villages. Towards its west end is Mount Grubor, and towards the east Mount Gradatz. At its east end is an islet, Mesa, behind which a vessel may be sheltered with any wind." J. PURDY, The New Sailing Directory for the Mediterranean Sea, the Adriatic Sea or the Gulf of Venice, the Archipelago and Levant, the Sea of Marmara and the Black Sea, 185. 
navedene. Naime, otok Mljet uistinu se nalazi 9 M odnosno 3 lige od Korčule, a širina Mljetskog kanala uglavnom je između 4,2 i 4,8 M, što je neznatno manje od spomenutih $5 \mathrm{M}$. Otok Mljet uglavnom je širok između 1,5 M i $2 \mathrm{M}$, što se podudara sa spomenutom širinom od $1 / 2$ lige, a navedena duljina od $20 \mathrm{M}$ takoder je zadovoljavajuće točna. Mljet je opisan vrlo slično kao u hrvatskom peljaru Peljar I. Jadransko more - istočna obala iz 2012. godine prema kojem je opisan kao brežuljkast i obrastao šumom s najvišim vrhom Veliki grad od $513 \mathrm{~m} .{ }^{89}$ Navodi o vrhovima Grabova glava $(383 \mathrm{~m})$ i Gradac $(377 \mathrm{~m})$ su točni. Međutim, kod spominjanja otočića Mesa, odnosno otočića Badanj, navod je pogrešan i ponavlja se greška iz peljara tiskanog 1811. godine. Naime, prema spomenutom navodu otočić je smješten na istočni kraj otoka Mljeta, iako je od njega, kako je već spomenuto, udaljen oko $6,5 \mathrm{M} .^{90}$

Kada usporedimo informacije o otoku Mljetu s prethodna dva peljara, tada se može utvrditi kako su u ovom peljaru informacije o udaljenostima preciznije, ali osim podatka o sidrištu u luci Sobra ne postoje nikakvi drugi praktični savjeti za plovidbu. Stoga, umjesto da se već postojeće informacije iz prethodna dva peljara nadopune, one su još oskudnije nego što su to bile prije 25 godina, odnosno u peljaru iz 1811. godine. Nakon opisa otoka Mljeta slijede dva ulomka koja opisuju Dubrovnik i Cavtat.

„Dubrovnik se nalazi $17 \mathrm{M}$ u smjeru SE za E [ESE $1 / 2 \mathrm{E}$ ] od istočnog kraja otoka Mljeta i smješten je na zapadnom kraju zaljeva koji je širok dvije lige. $\mathrm{Na}$ suprotnoj strani zaljeva nalazi se Cavtat (Ragusa Vecchia or Old Ragusa) u antici poznat kao Epidaurus. Dubrovnik se u prošlosti zvao Rausa, Turci ga nazivaju Pabrovica, a Slaveni Dobronich. Grad nije velik, ali je dobro izgrađen i sjedište je nadbiskupa. Zrak je čist i zdrav, ali je tlo toliko neplodno da stanovništvo mora većim dijelom uvoziti namirnice iz susjednih zemalja. Međutim, otoci zapadno od Dubrovnika su plodni, ugodni i prilično nastanjeni, a na njima se nalaze lijepi vrtovi. Na otoku Koločepu (Calamota), prvom od otoka zapadno od Dubrovnika, nalazi se crkva po kojoj je otok i prepoznatljiv. “91

89 Peljar I. Jadransko more - istočna obala, 268.

90 Pogreška je dodatno uvećana činjenicom kako na pomorskoj karti $A$ New Chart of the Mediterranean Sea iz 1826. godine uvala Sobra (Mezza Meleda) nije prikazana na samom E kraju otoka Mljeta kao što je to navedeno u peljaru. Pomorski muzej, Dubrovnik, A New Chart of the MEDITERRANEAN SEA, Comprebending the Coast from CAPE ST. MARY (IN PORTUGAL), TO CONSTANTINOPLE; and from RABAT IN AFRICA, TO ALEXANDRETTO, OR ISKENDEROON IN ASIA \& c. Reduced from the Late and Spanish and French Charts, made by Order of the respective GOVERNMENTS, With the recent Surveys of CAPTAIN W[illia]m H[enr]y SMYTH. R[oyal] N[avy], Capt[ai]n. F. Beaufort, R[oyal] N[avy] and other British Officers.

91 „RAGUSA is 17 miles S.E. by E. [E.S.E. 1/2 E.] from the East end of Melada, and stands on the west side of the bay which is two leagues in breadth. On the opposite side of the bay is Ragusa Vecchio, 
Prema navodima peljara, Dubrovnik je od otoka Mljeta udaljen $17 \mathrm{M} \mathrm{u}$ kursu približno $124^{\circ}$ (kompasni), odnosno približno $107^{\circ}$ (pravi). Iz navedenog se može utvrditi kako je magnetska varijacija u razdoblju tiskanja peljara za područje između Mljeta i Dubrovnika iznosila oko $17^{\circ} \mathrm{W} \cdot{ }^{92}$ Udaljenost od Mljeta do Dubrovnika dobro je procijenjena i nešto je preciznija nego u peljaru iz 1811. godine jer iznosi 16,2 M mjereno od subočice rta Debeli na Mljetu do subočice ulaza u dubrovačku staru gradsku luku. Spomenuti zaljev u kojem se prema navodima nalazi grad Dubrovnik je zaljev između Dubrovnika i Cavtata, koji obuhvaća područje Župskog zaljeva i Lokrumskog prolaza širine $6 \mathrm{M}$, odnosno 2 lige kako je navedeno. U prethodna dva peljara opisano se područje spominjalo pod imenom Bay of Ragusa odnosno Dubrovački zaljev.

Slijede informacije koje nisu suviše važne za plovidbu te spadaju u kategoriju općih informacija. ${ }^{93}$ Navedene informacije odnose se na ime i izgled grada koji je prema opisu „dobro izgrađen“ i za pretpostaviti je da se pri tome misli na zidine i utvrde koje okružuju grad, a navodi se i kako je Dubrovnik ujedno i sjedište nadbiskupije. ${ }^{94}$ Za zrak se napominje kako je zdrav i čist, što znači da u okolici nije bilo zemljišta kao što su močvare, bare i sl. koje bi ga činile nezdravim. Za peljar je neobičan podatak o neplodnosti tla što ima za posljedicu potrebu za uvozom hrane. ${ }^{95}$ Prilikom opisivanja Elafitskih otoka ponovo se kao i u peljaru iz 1811. godine spominje crkva na Koločepu po kojoj je otok prepoznatljiv. Međutim, ni u ovom peljaru nije preciziran smjer iz kojega brod treba ploviti kako bi se uočila navedena crkva.

or Old Ragusa, the antient Epidaurus. Ragusa was formerly called Rausa; by the Turks it is styled Pabrovica, by the Sclavonians Dobronich. It is not a large town, but well built, and the see of an archbishop. The air is wholesome, but the soil about it so barren that the inhabitants receive the greatest part of their necessaries from the neighbouring provinces: yet the islands on the coast north-westward are fertile, pleasant, well inhabited, and have beautiful gardens. On that called Calamota, next to the westward of Ragusa, is a church, by which it may be known."J. PURDY, The New Sailing Directory for the Mediterranean Sea, the Adriatic Sea or the Gulf of Venice, the Archipelago and Levant, the Sea of Marmara and the Black Sea, 185.

${ }_{92}$ U slučaju da je devijacija kompasa jednaka nuli.

93 Spomenute opće informacije navedene u peljaru istovjetne su onima iz knjige Geographical Dictionary or Universal Gazetteer tiskane 1817. godine te nisu od praktične vrijednosti za plovidbu. Ragusa, (Republic of,), u Joseph Emerson WorCester, Geographical Dictionary or Universal Gazetteer Vol II., Salem, 1817., b.o.s.

94 Navod je točan jer je nekoliko godina kasnije u sklopu preustroja crkvene organizacije u habsburškoj Kraljevini Dalmaciji provedenog 1830. godine Dubrovačka nadbiskupija svedena na razinu biskupije. Spomenuti preustroj izvršen je na temelju bule Locum Beati Petri Pape Leona XIII. objavljene 30. lipnja 1828. godine. Stjepan Ćosıć, Državna uprava u Dalmaciji i crkveni preustroj 1828./1830. godine, Croatica Christiana periodica, 34 (65), Zagreb, 2010., 51 - 66.

95 Spomenuta informacija mogla je poslužiti kao savjet kapetanima odnosno vlasnicima brodova kao sugestija o vrsti tereta za kojim bi u Dubrovniku vladala potražnja. 
„Dubrovnik je prepoznatljiv po crkvi koja se nalazi na brdu iznad grada, a također i po četiri otoka na ulazu u zaljev koji su međusobno prilično udaljeni, a između njih su prolazi u kojima su velike dubine. Na otoku najbližem Dubrovniku (udaljenom oko $1 \mathrm{M}$ ) nalazi se mala crkva (kapela) posvećena svetom Marku na geografskoj širini $42^{\circ} 37^{\prime} 45^{\prime \prime} \mathrm{N}$. Luka je izložena SW vjetrovima, ali je sigurno zaklonište. $\mathrm{Na}$ istočnoj strani zaljeva, odnosno ispred Cavtata se može sidriti na 8 - 6 hvati $(14,6-11 \mathrm{~m})$ dubine. ${ }^{\text {"996 }}$

Kao i prethodna dva, tako i ovaj peljar spominje pogrešan podatak o crkvi iznad grada i koji je očigledno prepisan iz peljara izdanog 1811 . godine. ${ }^{97}$ Podatak o četiri otoka je točan, međutim udaljenost otoka Lokruma, odnosno kako ga peljar naziva „otok najbliži Dubrovniku“, nije $1 \mathrm{M}$ od Dubrovnika nego 0,3 M. Također, na Lokrumu ne postoji crkvica (kapela) svetog Marka, nego crkva Naviještenja. Spominjanje crkvice (kapele) svetog Marka može se protumačiti i kao posljedica preuzimanja podataka tiskanih u Geographical Dictionary or Universal Gazetteer iz 1817. godine gdje se navodi kako je otok Chiroma, odnosno Lokrum, pripadao Veneciji. ${ }^{8}$ Pozicija crkvice (kapele) svetog Marka na geografskoj širini $42^{\circ} 37^{\prime} 45^{\prime \prime} \mathrm{N}$ približno odgovara poziciji utvrde Fort Royal koju u svojoj knjizi Mediterranean spominje William Henry Smyth, i to pod imenom Fort San Marco na poziciji $42^{\circ} 37^{\prime} 40^{\prime \prime} \mathrm{N} 18^{\circ} 06^{\prime} 54^{\prime \prime}$ E..$^{99}$

Gradska luka, odnosno sidrište, izložena je SE vjetru ili jugu (šiloku). Međutim, brodovi koji ne zađu dovoljno iza otoka Lokruma nego se usidre bliže

96 „Ragusa itself may be readily known by a church which stands on a mountain above it; also by four islets at the entrance of the bay, which lie at some distance from each other, with deep water channels between. Of these islets that nearest to Ragusa Point (about a mile off) has a small chapel on it, dedicated to St. Mark, situate in lat. $42^{\circ} 37^{\prime} 45^{\prime \prime}$. The harbour is exposed to the S.W. winds, but it is perfectly safe for ships to lie in. You may anchor off Old Ragusa, on the eastern side of the bay, in from 8 to 6 fathoms." J. PURDY, The New Sailing Directory for the Mediterranean Sea, the Adriatic Sea or the Gulf of Venice, the Archipelago and Levant, the Sea of Marmara and the Black Sea, 185- 186.

${ }_{97}$ Naime, Dubrovnik je u vrijeme tiskanja peljara već više od 15 godina bio prepoznatljiv po utvrdi Imperijal i koja se još uvijek nalazi na brdu Srđ iznad Dubrovnika.

98 Ragusa, (Republic of,), u J. E. WorCester, Geographical Dictionary or Universal Gazetteer Vol II., b.o.s. Spomenuta tvrdnja kako je otok Lokrum bio u posjedu Mletačke Republike odnosi se na događaje iz razdoblja od 1630. do 1635. godine i diplomatske borbe Dubrovnika s Venecijom za Lokrum Sušac i Molunat. Tada su Mlečani, koji su tijekom povijesti svojatali Lokrum nazivajući ga otokom Svetog Marka, u dva navrata nakratko i vojno okupirali otok srušivši pri tom i nekoliko građevina. U spomenutim oružanim incidentima nije bilo žrtava te su uslijedile diplomatske aktivnosti u svrhu rješavanja pitanja o suverenitetu nad Lokrumom. Tijekom pregovora mletačka je strana inzistirala da se za Lokrum koristi naziv „otok Svetog Marka“. Vinko Foretić, Povijest Dubrovnika do 1808. drugi dio, Zagreb, 1980., 98 - 102. Tako je i venecijanski peljar Vincenzo di Lucio kao autor pomorske karte područja Dubrovačke Republike otok Lokrum označio sa „S. Marco“. Pomorski muzej, Dubrovnik, Pomorska karta područja Dubrovačke Republike. 
gradskoj luci izloženi su i SW vjetru. Dubine za sidrište kod Cavtata su točne, ali nije navedeno drugo sidrište u uvali Tiha, kao ni hridi i pličine opisane u peljaru iz 1817. godine.

Iako je ovaj peljar najopsežniji od sva tri analizirana te je Jadranu posvećeno znatno više stranica, kvantiteta, a i kvaliteta informacija za dubrovačko područje se su smanjile. Upute su svedene uglavnom na opće informacije, a koje su od malog značaja za navigaciju. Navedeno može biti ujedno i jedan od pokazatelja opadanja važnosti Dubrovnika kao luke na globalnoj razini nakon propasti Dubrovačke Republike.

U podnaslovu „General Remarks on, and Directions for, the Adriatic Sea“ $u$ poglavlju X (str. 188 - 193) navedene su opće upute za plovidbu s obzirom na vjetrove, struje, vremenske prilike itd. Kao i u prethodnim peljarima, preporuka je da se u Jadran ulazi na istočnoj obali jer se tako izbjegne struja SE smjera. Za izlazak iz Jadrana također se preporuča plovidba uz istočnu obalu, jer je na zapadnoj obali samo Manfredonijski zaljev sigurno zaklonište od olujnih vjetrova N smjera. Peljar sadrži i upute kako i kojim kursovima ploviti da bi se stiglo do Venecije i Trsta za što je, između ostalog, bilo potrebno ukrcati i peljara u Rovinju ili Poreču. Navodi se kako morske mijene i morske struje u Jadranu nisu dovoljno istražene na znanstvenoj osnovi i kako su na istočnoj obali Jadrana morske struje uglavnom $\mathrm{N}$ smjera, a na zapadnoj uglavnom S i SE te promjenjivih smjerova. Spomenuto je samo po sebi dovoljan razlog za korištenje istočne obale u plovidbi prema sjevernom Jadranu. Peljar napominje i kako postoje razna odstupanja u smjerovima i brzini morskih struja koja su uzrokovana vjetrom, morskim mijenama i godišnjim dobima. Veći dio općih uputa sastoji se od opisa morskih struja, kao i međusobne povezanosti vjetrova i morskih struja. Spominje se i područje Dubrovnika za koje se navodi kako su morske struje nepravilne i promjenjive, međutim njihovi smjerovi i brzine nisu navedeni. ${ }^{100}$

Kao i u prethodno analiziranom peljaru iz 1817. godine, podatci o strujama većim su dijelom temeljeni na zapažanjima venecijanskog peljara Vincenza di Lucia i njegova djela iz 1798. godine o morskim strujama u Jadranu. ${ }^{101}$ Međutim, unatoč relativno opširnom opisu morskih struja, u peljaru ne postoje podatci o vjetrovima, odnosno o tome koji vjetrovi prevladavaju u određenim razdobljima, a ne postoje ni opisi ni upozorenja o vjetrovima, kao što je to slučaj u suvremenim peljarima.

100 J. Purdy, The New Sailing Directory for the Mediterranean Sea, the Adriatic Sea or the Gulf of Venice, the Archipelago and Levant, the Sea of Marmara and the Black Sea, 188.

101 Spomenuto djelo Trattato delle correnti del golfo Adriatico u vrijeme tiskanja peljara već je 20 godina bilo dostupno engleskoj javnosti jer je 1806. godine tiskano na engleskom jeziku. Peljar stoga detaljno opisuje djelovanje morskih struja po mjesecima u godini, kao i utjecaj vremenskih prilika na morske struje. 
Zajedničko s ostalim analiziranim peljarima je i činjenica da su opće upute za plovidbu Jadranom prikazane na kraju poglavlja, što je također razlika od suvremenih peljara u kojima se obično prvo navode opće upute i podatci, a zatim slijede pojedinačni opisi.

Značajan detalj po kojem se peljar iz 1826. godine razlikuje od prethodno analiziranih peljara je dodatak koji se nalazi na kraju peljara pod naslovom Addenda i koji sadrži razne informacije koje bi se mogle koristiti u praksi, a po čemu je ovaj peljar sličan današnjima. Neke od informacija navedenih u dodatku su primjerice ruža vjetrova na francuskom, talijanskom i turskom jeziku, zatim engleski prijevodi nekih grčkih i turskih riječi i imena koja se obično koriste na kartama te bilješke o malteškim i turskim mjerama i novcu. ${ }^{102}$

\section{ZAKLJUČAK}

Gledano iz današnje perspektive, kada je pomorcima dostupna najsuvremenija navigacijska oprema, a u prvom redu GPS uređaji koji daju gotovo savršeno točnu poziciju broda u realnom vremenu, te elektronske karte integrirane s GPSom, informacije $u$ analiziranim peljarima čine se vrlo oskudnim i manjkavim. Međutim, na početku 19. stoljeća navodi u analiziranim peljarima za tadašnje pojmove bili su iznimno kvalitetne, a ponekad i jedine dostupne informacije o mnogim dijelovima svijeta koji su tada smatrani perifernima.

Vidljivo je kako se tijekom obrađivanog razdoblja Jadran u engleskim peljarima opisivao samo u sklopu Sredozemlja, odnosno kao njegov mali i manje važan dio. Stoga su podatci i upute koji se odnose na plovidbu Jadranskim morem vrlo oskudni. Uzimajući u obzir navedeno, nameće se zaključak kako je Jadransko more na globalnoj razini smatrano manje važnim plovidbenim područjem.

Detaljnom analizom i usporedbom sa stvarnim stanjem utvrđeno je kako su upute za plovidbu dubrovačkim akvatorijem prilično manjkave te sadrže veliki broj pogrešaka. Nažalost, zbog neprijateljstava između Velike Britanije i Francuske nisu bili dostupni podatci o izmjerama koje je početkom 19. stoljeća na Jadranu vršio čuveni francuski istraživač Beautemps-Beaupré. Navedene izmjere bile su prve izmjere Jadrana na znanstvenoj osnovi te je sigurno kako su analizirani peljari ostali uskraćeni, a time i znatno osiromašeni za mnoštvo korisnih informacija o Jadranu. 
Ukupno gledajući, za plovidbu dubrovačkim akvatorijem od rta Vratnik do rta Oštra s okolnim otocima, uključujući i otok Mljet, najkorisniji je peljar The New Mediterranean Pilot autora J. W. Norieja iz 1817. godine. Iako od tri analizirana peljara spomenuti peljar nije najnoviji, ipak sadrži neke vjerodostojne informacije koje su bile korisna nadopuna tadašnjim pomorskim kartama. Naime, informacije u peljaru autora J. Purdyja iz 1826. godine bitno su lošije kvalitete i uglavnom se svode na opće geografske informacije navedene u knjizi Geographical Dictionary or Universal Gazetteer Vol II. iz 1817. godine i koja ni ne spada u pomorske publikacije. Pri tome treba spomenuti i loš odabir informacija preuzetih iz spomenute knjige jer se u njoj nalaze i određene informacije o Dubrovniku koje bi pomorcima mogle biti od koristi. Iako su takve informacije danas sastavni dio pomorskih publikacija kao što su peljari, one nažalost nisu bile uključene u peljar iz 1826. godine. Uz relativno kvalitetne informacije za plovidbu dubrovačkim akvatorijem, peljar iz 1817. godine sadrži i dobre opće upute i informacije za plovidbu Jadranom, a koje su znatno opširnije i kvalitetnije nego u peljaru iz 1811. godine. Za usporedbu, opće informacije o plovidbi Jadranom iz peljara autora J. Purdyja izdanog 1826. godine većim su dijelom istovjetne onima iz Noriejeva peljara iz 1817. godine stoga nisu bitno kvalitetnije unatoč vremenskoj razlici od devet godina.

$\mathrm{Na}$ primjeru analiziranih peljara očigledno je kako je bilo potrebno dulje razdoblje kako bi se pojedine informacije ispravile odnosno ažurirale, dok su neke i desetljećima ostajale nepromijenjene. Međutim, tijekom prošlosti vladala je uobičajena praksa da se za tiskanje novih upotrebljavaju već postojeće karte i publikacije koje bi se jednostavno nanovo pretiskale uz male ili nikakve izmjene, i to bez da se vrše nova istraživanja. U današnje vrijeme takvo nešto je nedopustivo, stoga se danas pomorske karte i publikacije ispravljaju i ažuriraju na tjednoj ili mjesečnoj osnovi, što uvelike doprinosi istinitosti i pouzdanosti informacija.

$\mathrm{Na}$ kraju je potrebno napomenuti i kako su sva tri engleska peljara izdana prvenstveno kao upute za plovidbu Sredozemljem, čiji je Jadran samo manji dio. Stoga i nije bilo za očekivati da će informacije o relativno malom području Jadrana kao što je to dubrovački akvatorij od rta Vratnik do rta Oštra s okolnim otocima, uključujući i otok Mljet, biti znatno opširnije. Situacija će se bitno promijeniti u drugoj polovici 19. stoljeća izdavanjem engleskog peljara The Adruiatic Pilot 1861. godine te kasnijim publikacijama u izdanju Hidrografskog ureda Ujedinjenog Kraljevstva u koje spadaju i Admiralty Sailing Directions. Najnovijim izdanjem Admiralty Sailing Directionsa područje Sredozemlja obuhvaćeno je u pet knjiga, od kojih je jedna u cijelosti posvećena Jadranu, što dovoljno prikazuje napredak na području pomorskih publikacija odnosno peljara koji je postignut od početka 19. stoljeća do danas. 


\section{IZVORI I LITERATURA}

\section{IZVORI:}

Pomorski muzej, Dubrovnik, A New Chart of the MEDITERRANEAN SEA, Comprehending the Coast from CAPE ST. MARY (IN PORTUGAL), TO CONSTANTINOPLE; and from RABAT IN AFRICA, TO ALEXANDRETTO, OR ISKENDEROON IN ASIA \& c. Reduced from the Late and Spanish and French Charts, made by Order of the respective GOVERNMENTS, With the recent Surveys of CAPTAIN W[illia]m H[enr]y SMYTH. R[oyal] N[avy], Capt[ai]n. F. Beaufort, R[oyal] N[avy] and other British Officers, William Henry Smyth, Francis Beaufort, 1826., Zbirka pomorskih i zemljopisnih karata i atlasa, inv. br. DUM PM 885.

Pomorski muzej, Dubrovnik, Meleda, Tobias Oesterreicher, 1879., Zbirka pomorskih i zemljopisnih karata i atlasa, inv. br. DUM PM 990.

Pomorski muzej, Dubrovnik, Pomorska karta područja Dubrovačke Republike, Vincenzo di Lucio, ca. 1800., Zbirka pomorskih i zemljopisnih karata i atlasa, inv. br. DUM PM 227.

\section{LITERATURA:}

Bibliotheca Britannica, Volume II., Edinburgh, 1824.

Ćosıć, Stjepan, Državna uprava u Dalmaciji i crkveni preustroj 1828./1830. godine, Croatica Christiana periodica, 34 (65), Zagreb, 2010., 51 - 66.

DAvid, Andrew, British Hydrographic Surveys in the Mediterranean in the early years of the Nineteenth Century, International Hydrographic Review, 6 (3), Monaco, 2005., 10 - 24.

Dictionary or National Biography, Vol. XXXII., (ed. Sidney Lee), New York London, 1892.

Dictionary or National Biography, Vol. XLI., (ed.Sidney Lee), New York - London, 1895.

Dictionary or National Biography, Vol. XLVII., (ed. Sidney Lee), New York London, 1896.

FARIČić, Josip, Mirošević, Lena, Carta di cabotaggio del Mare Adriatico (1822-1824): A Turning-Point in the Development of Adriatic Maritime Cartography, Imago mundi, 69(1), 2017., $99-111$.

Foretić, Vinko, Povijest Dubrovnika do 1808. drugi dio, Zagreb, 1980. Kozličić, Mithad, Istočni Jadran u djelu Beautemps-Beaupréa, Split, 2006. 
Kozlıčıć, Mithad, Pomorske karte i plovidbeni priručnici istočnog Jadrana tijekom povijesti, Miscellanea Hadriatica et Mediterranea, 1 (1), Zadar, 2013., $169-197$.

Laurie and Whittle's New Sailing Directions for the Mediterranean Sea, London, 1811.

MAgAš, Damir, FARIČıć, Josip, Surić, Maša, Elafitsko otočje - fizičko geografska obilježja u funkciji društveno-gospodarskog razvitka, Geoadria, 6 (1), Zadar, 2001., 31 - 55 .

New Sailing Directions for the Mediterranean Sea, the Adriatic, or Gulfof Venice, the Black Sea, Grecian Archipelago, and the Seas of Marmara and Azov, London, 1841.

Norie, John William, The New Mediterranean Pilot, London, 1817.

Peljar I. Jadransko more - istočna obala, Split, 2012.

Peljar po Jadranu I. dio istočna obala, Split, 1952.

Peljar po Jadranu II. dio zapadna obala, Split, 1953.

Piplović, Stanko, Graditeljstvo u Dalmaciji za francuske uprave, u: Adris, Zbornik radova, ur. Davorin Rudolf, Zagreb-Split, 2012., 75 - 102.

Pomorska karta MK-25 Ston, Split, 2015.

Pomorska karta MK-26 Dubrovnik, Split, 2015.

Pomorska karta MK-27 Boka kotorska, Split, 2015.

Pomorski leksikon, gl. ur. Anton Simović, Zagreb, 1990.

Pravilnik o službenim pomorskim navigacijskim kartama i publikacijama, njihovom sadržaju, načinu i uvjetima izrade, Narodne Novine 42/2016, 4. 5. 2016.

Purdy, John, The New Sailing Directory for the Mediterranean Sea, the Adriatic Sea or the Gulf of Venice, the Archipelago and Levant, the Sea of Marmara and the Black Sea, London, 1826.

Regan, Krešimir, NAdilo, Branko, Ranoromaničke i predromaničke crkve na Koločepu (I.), Gradevinar, 58 (4), Zagreb, 2006., 317 - 323.

REgAN, Krešimir, NADilo, Branko, Ranoromaničke i predromaničke crkve na Koločepu (II.), Građevinar, 58 (5), Zagreb, 2006., 405 - 412.

Slukan Altić, Mirela, The British Contribution to the Charting of the Adriatic Sea, The Cartographic Journal, 52(4), 2015., 305 - 317.

Sмутн, William Henry, The Mediterranean, London, 1854.

SOLAS Consolidated Edition 2014, London, 2014.

The Adriatic Pilot, London, 1861. 
The Dictionary of Physical Geography, gl. ur. David S. G. Thomas, Hoboken, 2016., 326.

WorCester, Joseph Emerson, Geographical Dictionary or Universal Gazetteer Vol II., Salem, 1817.

\section{INTERNETSKI IZVORI:}

Laurie and Whittle's New Chart of the Mediterranean Sea, http://digitalarchive. mcmaster.ca/islandora/object/macrepo\%3A79186, posjećeno 10.9. 2020.

New Chart of The Mediterranean Sea, https://www. loc.gov/item/2012593220/, posjećeno 10.9. 2020.

Vicenzo di Luccio, Treatise on the Currents in the Gulf of Venice, https://discovery.nationalarchives.gov.uk/details/r/C8868901, posjećeno 10. 9. 2020. 
Daniel DUJMIĆ

\section{NARROWER DUBROVNIK AQUATORIUM IN ENGLISH MARITIME PILOTS FROM 1811 TO 1826}

\section{SUMMARY}

The paper analyses data about the waterways of Dubrovnik from the southernmost cape of the Pelješac peninsula, Cape Vratnik to Cape Oštra with the surrounding islands, including the island of Mljet, published in three English works on navigation printed in the first half of the 19th century $(1811,1817$ and 1826). These pilots were the forerunners of today's official maritime publications and contained information and instructions for sailing the Adriatic Sea, or the Gulf of Venice as the Adriatic Sea was then called, and were used as a supplement to nautical charts. The Adriatic was described as part of the Mediterranean in the analysed pilots, i.e., its more minor and lesser important role. Therefore, the number of pages dedicated to navigation in the Adriatic Sea was relatively small.

The information and instructions presented in the mentioned pilots for the Dubrovnik waterways from the southernmost cape of the Pelješac peninsula, cape Vratnik to cape Oštra with the surrounding islands, including the island of Mljet, were analysed in detail and compared with the actual situation according to relevant historical sources and nautical charts, as well as contemporary Croatian nautical charts and publications published by the Croatian Hydrographic Institute. This determined the accuracy and reliability of the published data and their aberration from the actual situation.

From today's perspective, the information in the analysed maritime guides is very scarce and deficient and often wrong. However, in the first half of the 19th century, pilot books were often the only available information about many parts of the world, then considered peripheral. The Adriatic Sea was one of such "peripheral" parts of the world since it did not represent an important maritime area during the first half of the 19th century.

All three analysed pilots followed the practice of the time. The already existing charts and publications were used to print new ones, reprinted with little or no change and without further research. At the same time, it took a more extended period for specific information to be corrected or updated, while some remained unchanged for decades. Overall, for navigating the Dubrovnik waterways from Cape Vratnik to Cape Oštra with the surrounding islands, including the island of Mljet, the most helpful pilot book was The New Mediterranean Pilot from 1817 
by J. W. Norie. It contained some credible information that served as a valuable supplement to the then nautical charts.

Keywords: maritime publications, maritime pilots, Dubrovnik waterways, 19th century, Adriatic Sea. 